\title{
Processes affecting groundwater quality in arid zones: the case of the Bou- Areg coastal aquifer (North Morocco)
}

\author{
Re V. ${ }^{*}$, Sacchi E. ${ }^{2}$, Martin-Bordes J.L. ${ }^{3}$, Aureli A. ${ }^{3}$, El Hamouti N. ${ }^{4}$, Bouchnan R. ${ }^{5}$, Zuppi \\ G.M. ${ }^{1,6}$
}

${ }^{1}$ Department of molecular sciences and nanosystems, University Ca' Foscari of Venice. Dorsoduro-Calle Larga Santa Marta 2137. 30123 Venice, Italy

${ }^{2}$ Department of Earth and Environmental Sciences, University of Pavia, Pavia, Italy

${ }^{3}$ UNESCO-IHP, 1 rue Miollis, 75732 Paris Cedex 15, France

${ }^{4}$ Multidisciplinary Faculty of Nador, University of Oujda, Nador, Morocco

${ }^{5}$ Laboratory of Physical Phenomena and Natural Risk Modelling, University of Tanger, Tanger, Morocco

${ }^{6}$ Institute of Environmental Geology and Geoengineering, National Research Council (CNR), Monterotondo, Italy

*Corresponding author, Email: re@unive.it;

\begin{abstract}
The coastal aquifer of Bou-Areg (Morocco) has been studied to identify the main processes causing groundwater salinization, using a multi tracer (general chemistry and isotopes- $\left.\delta^{2} \mathrm{H}, \quad \delta^{18} \mathrm{O}, \quad \delta^{13} \mathrm{C}, \quad \delta^{15} \mathrm{~N}_{\mathrm{NO} 3}, \quad \delta^{18} \mathrm{O}_{\mathrm{NO} 3}\right)$ geochemical approach. Groundwater is characterized by the widespread occurrence of brackish waters (TDS $<500 \mathrm{mg} \mathrm{L}^{-1}$ ) with high cation contents, which are balanced by elevated dissolved $\mathrm{NO}_{3}^{-}$(reaching a maximum of 208 $\mathrm{mg} \mathrm{L}^{-1}$ ) and $\mathrm{Cl}^{-}$. Lagoon samples represent a mixture of fresh water and sea water, showing a $\mathrm{Na} / \mathrm{Cl}$ ratio in agreement with that of sea water and an excess of $\mathrm{Ca}$. The high $\mathrm{Ca}$ values represent the main peculiarity of the groundwater-lagoon water system. Two types of groundwater could be identified: (i) freshwater, separated from the whole system and located at the limit of the irrigated area, characterized by low TDS, depleted isotopic composition and relatively high quality; and (ii) water mainly recharged by mountain runoff, interacting with local recharge and acquiring salinity from different sources, thus creating a complex system of dilute waters. Hydrochemical results confirm that the high salinity of the aquifer is caused by the coexistence of dissolution of evaporate rocks and carbonates from Miocene strata, water-rock interaction, and human impacts due to agricultural return flows. The latter represents the main contribution to groundwater salinization, especially in the central part of the aquifer, as well as one of the main causes of the general increase in $\mathrm{NO}_{3}{ }^{-}$concentrations. Only locally, in the southern part of the aquifer, close to the city of Kariat Arkmane, the high salinization observed may be attributed to the presence of lagoon water intrusion. The isotopic composition of dissolved $\mathrm{n} \mathrm{NO}_{3}{ }^{-}$indicates manure and septic effluents, especially in urban areas and in the central part of the plain, and synthetic fertilizers in the agricultural zone as the main drivers for human induced pollution. The study shows that agricultural return flow has significantly modified the chemistry of the system and it is a prime example of the humaninduced changes over coastal environments. Saline water intrusion from the lagoon in the shallow aquifer is negligible, while discharge of polluted groundwater into the lagoon has been found to partially alter its quality.
\end{abstract}

\section{Introduction}

Aquifers represent an important source of renewable freshwater in most coastal plains, and are largely exploited to respond to human needs. Sustainable water management has become an issue of major concern in the Mediterranean basin over the past decade because of the increasing water stress, mainly in coastal areas. These areas are also experiencing an increase in population, due to the combined action of internal migration and demographic growth, causing a rise of water demand. As a consequence, in arid and semi-arid regions, where the alluvial aquifers are tapped by a large number of wells, abstraction rates often 
exceed natural replenishment rates, leading to over-exploitation (Vanenschrick et al., 2002; Bakalowicz et al., 2003; Bakalowicz, 2006; Bouchaou et al., 2008; Re and Zuppi, 2011).

Moreover, salinization of soils and underground resources is a problem of particular relevance in coastal areas, especially in arid and semi-arid regions (Rosenthal et al., 1992; Mas-Pla et al., 1999; Sanchez-Martos et al., 2002; Faye et al., 2005; Di Sipio et al., 2006; Panno et al., 2006; Bouchaou et al., 2008; Lenahan et al., 2010; Re et al., 2011). The extent and importance of salinization as a global threat has been greatly underestimated (Williams, 1999). In the unsaturated zone, natural salinization can either be due to the presence of marly gypsum-bearing terrains, or be associated with marine aerosols. In particular, marine sprays (either transported as liquid drops or evaporated materials) and airborne marine salts can contribute to the base cation content in coastal soils (Art et al., 1974; Whipkey et al., 2001). Water evaporation surfaces, such as ponds, lakes or, as in the case of the Bou-Areg plain, open irrigation channels, could also yield saline waters that might enter the ground, possibly favoured by the increased water density (Custodio, 2004). In addition, irrigation return flows can alter natural groundwater salinity (Llamas and Custodio, 2003).

In groundwater, when the dynamic balance between shallow freshwater and saline water is disturbed, the encroachment of saline water can occur. In most cases, salinization processes are due to sea water intrusion and deep saline water upwelling, i.e. to inland flow of saline dense water during heavy withdrawals of fresh water from coastal aquifers (Custodio, 2002; Edmunds, 2003; Faye et al., 2005; Vengosh, 2003), or mobilisation of saline formation waters by the over-exploitation of inland aquifer systems (Giménez-Forcada et al., 2009). Groundwater is a diluting agent, therefore, an inverse relationship between the discharge rate and salinity is generally observed. A similar relationship can be seen where salinity is imparted by geological formations through the dissolution of evaporites or through other water-rock interaction processes: increased flushing then results in lower water salinity (Gat and Naor Tahal, 1979). More complicated relationships occur when the salinity is incorporated in a salt-fresh water boundary zone (Mazor and Molcho, 1972), possibly as a result of brine pockets left behind by a receding sea. In this case, the origin of salinity is to be found in the geological past.

Understanding processes leading to groundwater salinization in present coastal plains often involves an understanding of their past morphologic conditions, their recent geological evolution and how these can affect hydrodynamics and hydrochemistry. The accumulation and release of salinity from the near surface takes place naturally as a result of climatic cycles. This phenomenon, in the saturated and unsaturated zones of aquifers, may create archives of environmental and climatic changes in the investigated area. Indeed, information on palaeoclimate is encoded in groundwater in a variety of measurable geochemical and isotopic "tracers", allowing reconstruction of past environmental changes (Gasse et al., 1987; Fontes and Gasse, 1991; Edmunds and Droubi, 1998; Green et al., 2011).

In the Mediterranean basin, many aquifers are exposed to the combined action of climatic and environmental changes coupled to increasing human pressure (Zuppi, 2008; Re and Zuppi 2011). Human intervention through groundwater development has greatly altered the distribution of natural salinity. Economic growth has led to urbanization, irrigation and industrialization, producing an overall rise in mineralization of groundwater in parallel with pollution of various kinds. In particular, intensive anthropogenic activity in peri-urban and agricultural areas often results in high $\mathrm{NO}_{3}^{-}$concentrations, exceeding drinking water standards (Abiodun 1997; Oga Yei et al. 2007; Akouvi et al. 2008; Re et al., 2011). In addition, the impacts on natural water quality might result in it being inadequate for irrigation purposes, also poing serious threats to the health of the inhabitants of the areas concerned (Fan and Steinberg 1996).

Both natural and anthropogenically-induced salinization, together with quality changes in the hydrological cycle, are better understood if approached with the help the best available tools, i.e. a combination of isotopic and geochemical methods interpreted in a hydrological context (Edmunds and Drubi, 1998). 
Considering the important role that coastal aquifers and groundwater play in the sustainable management and protection of coastal areas in the Mediterranean basin, UNESCO-IHP is executing the sub-component on "Management of Coastal Aquifers and Groundwater" of the GEF-funded UNEP/MAP (Mediterranean Action Plan) Strategic Partnership for the Mediterranean Sea Large Marine Ecosystem (MedPartnership). This Partnership represents the first multi-agency project that brings together some of the main partners working in the Mediterranean region for joint action towards its protection and environmental conservation (UNEP, 2010). The Italian Ministry for Environment, Land and Sea contributes to this initiative through UNESCO-IHP, supporting a study in the region of Nador (NE Morocco). The overall objective of the study is to identify the possible human impact on groundwater quality and the occurrence of submarine discharge of polluted groundwater to the marine environment.

In particular, the investigation reported in this paper aims to determine the main sources of recharge and salinization in the Bou-Areg aquifer, stressing the importance of the geological setting for the baseline hydrogeological characteristics and the influence of the aquifer on the lagoon of Nador. Moreover, as the plain is mainly characterized by the combined actions of urban and agricultural activities, special attention is paid to the identification of the main sources of $\mathrm{NO}_{3}{ }^{-}$contamination.

\section{Site description}

The Bou-Areg coastal plain is located on the Mediterranean shore of Morocco, close to the border with Algeria (Fig. 1). The alluvial plain covers an area of about $190 \mathrm{~km}^{2}$ and is limited by the Gourougou volcanic massif (NW), the Beni-Bou-Ifrour massif and the Kebdana range (SE). To the south the plain is connected to the Gareb plain through the Selouane corridor, while the northern border coincides with the so-called lagoon of Nador, locally known as Sebka Bou-Areg (or Marchica). This coastal lagoon has a surface of $115 \mathrm{~km}^{2}$ and a depth not exceeding $8 \mathrm{~m}$ (Umgiesser et al., 2005). It is characterized by semidiurnal tides and has micro tidal regime as the water levels range from roughly $0.1 \mathrm{~m}$ at neap tide to around 0.5 $\mathrm{m}$ at spring tide (Brethes and Tesson, 1978; Umgiesser et al., 2005). The salinity varies from 39.5 to 43.5 psu over the year (Umgiesser et al., 2005), slightly exceeding sea water concentration.

The climate of the region is mainly semi-arid, but with a general high level of humidity due to the proximity of the sea. The dominant winds move in a W-SW direction from November to May and E-NE between May and October (Tesson, 1977). There is no regular rainy season, and regional precipitation is mainly related to Atlantic perturbations, with an average rainfall of about $300 \mathrm{~mm} / \mathrm{a}$ (El Yaouti et al., 2009).

Soils in the northern part of the plain are dominated by the presence of minerals such as Ca-plagioclase, silica, olivine and pyroxene deriving from the Gourougou Mountain, while soils in the southern part are rich in quartz, calcite and clays. In particular, the clay fraction is dominated by illite and chlorite (Bloundi, 2005), which generally characterize areas of weak pedologic evolution, such as young soils or, as in this case, arid and semi-arid regions.

The plain is characterized by the presence of salt marshes, rivers with temporary flow (oued), some of which often serve as sewage outflows for urban areas upstream (Gonzales et al., 2007), and only a few permanent rivers (the most important of which is the Selouane oued). Some oueds discharge directly into the lagoon of Nador contributing, together with the underground water flow, to its freshwater and sediment inputs, while others do not reach the lagoon because of flow reduction due to evaporative loss or infiltration into the aquifer. In addition to surface water contributions, sewage and wastewaters inputs are also present and are mainly associated with the urban and suburban settlements on the lagoon shore (SE: Kariat Arkmane; NW: Beni-Enzar).

The recharge of the Bou-Areg aquifer is provided by groundwater from the Gareb aquifer (Fig. 1), rainwater, freshwater from the Selouane oued (as the main surface drainage), and 
waters coming from the irrigation channel network (El Yaouti et al., 2009). On the other hand, the Lagoon of Nador represents the main outlet of the Bou-Areg aquifer.

Several authors have studied the hydrogeology of the Bou-Areg system (Carlier, 1971; Tesson, 1977; Brethes and Tesson, 1978; Tesson and Gensous, 1981) providing the basis for all the recent studies, and allowing the identification of the main features of the aquifer. Based on nearly 30 boreholes covering the whole plain, Chaouni Alia et al. (1997) investigated the structure of the aquifer, which is composed of late Pliocene and early Quaternary deposits. The authors identified four main formations, grouping into different layers (Fig. 2), with similar hydrological behaviour:

- Formation I (F1) corresponds to the upper layer, and is composed of fine material with lower permeability, including silts, clayey silts, encrusted limestone and marlcalcareous tufa that may contain gravels. These deposits have a thickness ranging between 0 and $44 \mathrm{~m}$, with permeability of the order of $10^{-5} \mathrm{~ms}^{-1}$.

- Formation II (F2) is the lower part of the aquifer reservoir, grouping coarser elements with high permeability (order of $10^{-4} \mathrm{~ms}^{-1}$ ), like pebbles, gravels of volcanic or sedimentary origin, and sands. The depth of this formation varies from 8 to $74 \mathrm{~m}$.

- Formation III (F3) has a composition similar to that of Formation I, composed of fine sediments with permeability of $10^{-5} \mathrm{~ms}^{-1}$. This formation varies in thickness from 0 to $97 \mathrm{~m}$.

- Formation IV (F4), reached only by the deeper boreholes, is nearly impermeable. It is constituted by clays and marls of Pliocene age, and contains gypsum, resulting from the Messinian Salinity Crisis. This formation represents the impervious bed to the upper Quaternary aquifer dipping towards the lagoon.

Therefore, the Plio-Quaternary formations of Bou-Areg basin form an unconfined aquifer limited to the bottom by the Pliocene substratum of gypsiferous marls (El Yaouti et al. 2009). The aquifer in Formation II is bounded on the top and bottom by two less permeable layers, Formation I and Formation III, respectively. Formation IV (thickness of 56-66m) is assumed to be the impermeable substratum (Chaouni Alia et al., 1997).

The geometry of Formation II shows a series of "valleys", oriented perpendicularly to the lagoon shore (Fig. 2). The maximum depth of these valleys is found in the central part of the plain (East of the Selouane oued) and in the valley of Kariat Arkmane.

As a general feature, many authors (El Mandour et al., 2008; El Yaouti et al., 2008, 2009) have concluded that the aquifer has good hydrodynamic characteristics, mainly associated with high permeability (reaching $7 \cdot 10^{-4} \mathrm{~m} \mathrm{~s}^{-1}$ in the vicinity of the lagoon and in the western zone, while the lowest values are found at the borders of the Kebdana massif). According to El Yaouti et al. (2009), transmissivity varies continuously from upstream to the coastal zone, ranging from $9 \cdot 10^{-4}$ to $2 \cdot 10^{-2} \mathrm{~m}^{2} \mathrm{~s}^{-1}$. The highest values are found in the west (north of the plain), whereas the lowest are measured at the borders of the Kebdana massif, probably due to the accumulation of marls. All along the coast, the transmissivity is about $2 \cdot 10^{-2} \mathrm{~m}^{2} \mathrm{~s}^{-1}$.

The region of Nador, as with many other coastal plains in the Mediterranean area, is characterized by intense agricultural activities, covering more than $62 \%$ of the total surface area (El Yaouti et al., 2008) and with only $20-40 \%$ of land equipped for irrigation land (FAO, 2012). No information is available in the literature about agronomical practices, but the absence of large animal farms in the Bou-Areg area implies little production of manure, with the consequent dominant use of synthetic fertilizers.

\section{Materials and Methods}

Two sampling campaigns in November 2009 and June 2010 (Fig. 3) allowed the collection of a total of forty groundwater samples from private wells in the Bou-Areg aquifer, eighteen lagoon water samples (L18 collected at the inlet level) and two spring samples (S1 and S2) located close to the lagoon shore. One sample (P10) was also collected in the adjacent 
Gareb Plain. Sampling was carried out in Fall and Spring in order to obtain information about seasonal effects and possible local recharge in the area (Re, 2011).

Electrical Conductivity, $\mathrm{pH}, \mathrm{Eh}$, groundwater temperature and alkalinity were measured directly in the field. Samples for major ion analysis were stored in polyethylene bottles and filtered in the laboratory through $0.45 \mu \mathrm{m}$ cellulose membrane within $24 \mathrm{~h}$ from sampling. Samples for cation analysis were preserved by addition of $5 \mathrm{~N} \mathrm{HNO}_{3}$ just after filtration. Samples for stable isotope analysis were collected and preserved according to the procedures indicated by Clark and Fritz (1997).

Chemical analyses of water samples were performed at the hydrochemical laboratory of CNR-IGAG (Montelibretti, Italy) (November 2009 campaign), and at the hydrochemistry laboratory of the Earth and Environmental Sciences Department at the University of Pavia (Italy) (June 2010 campaign), using ion chromatography. The error based on the ionic balance was calculated to be $<5 \%$. Trace element analyses (B, Li, Sr) were performed at the Earth and Environmental Sciences Department at the University of Pavia (Italy), using ICP-AES (Jobyn Yvon 24). Bromide analyses were performed at the CNR-IGG (Pisa, Italy) using ion chromatography.

Hydrogen isotope composition was measured by water reduction over metallic $\mathrm{Zn}$ (Coleman et al., 1982), while $\delta^{18} \mathrm{O}$ was analysed by water- $\mathrm{CO}_{2}$ equilibration at $25^{\circ} \mathrm{C}$ (Epstein and Mayeda, 1953); both results are expressed in \%o vs V-SMOW (Gonfiantini, 1978; Gonfiantini et al., 1995). The analytical errors are \pm 1 and $\pm 0.1 \%$, respectively. The $\delta^{13} \mathrm{C}$ of DIC was determined by direct acidification of the water sample with phosphoric acid (Kroopnick, 1974). Results are expressed in \%o vs V-PDB (Gonfiantini, 1978; Gonfiantini et al., 1995). Analytical errors are \pm 0.3 . The $\delta^{15} \mathrm{~N}_{\mathrm{NO} 3}$ and $\delta^{18} \mathrm{O}_{\mathrm{NO} 3}$ of dissolved $\mathrm{NO}_{3}{ }^{-}$were determined following the procedures described by Kendall and Grim (1990) and by Silva et al., (2000) and quoted relative to V-AIR and V-SMOW (Gonfiantini et al., 1995); the analytical errors are $\pm 0.5 \%$ and $\pm 1 \%$, respectively. All samples were prepared and analysed on a Finningan ${ }^{\mathrm{TM}}$ MAT 250 Mass Spectrometer at ISO4 s.n.c., Turin, Italy.

\section{Results}

\subsection{Groundwater}

Groundwater sampled in June 2010 had temperatures between 19.7 and $28.2{ }^{\circ} \mathrm{C}$, with an average of $22.4{ }^{\circ} \mathrm{C}$ (Table 1). Those values are typical of cold-hypothermal waters, and reflect the seasonal temperature increase from November 2009. Values of $\mathrm{pH}$ range from 7.2 (P30) to 7.9 (P28), being neutral or slightly alkaline nature. Electrical conductivity confirms high groundwater mineralization (average of $5.97 \mathrm{mS} \mathrm{cm}^{-1}$ ), with a maximum value in well 4 $\left(10.52 \mathrm{mS} \mathrm{cm}^{-1}\right)$ and a minimum in well $5 \mathrm{~b}\left(1.74 \mathrm{mS} \mathrm{cm}^{-1}\right)$. Spring samples show higher conductivity (7.94 and $15.66 \mathrm{mS} \mathrm{cm}{ }^{-1}$, respectively), highlighting the influence of lagoon water, and suggesting the occurrence of mixing processes.

Redox potentials are positive for all the samples (mean value $+178 \mathrm{mV}$ ) but for well $5 \mathrm{~b}(-$ $8 \mathrm{mV}$ ). The groundwater (Table 2) have high cation contents, which are not balanced by the low alkalinity values (mean alkalinity value: $518 \mathrm{mg} \mathrm{L}^{-1}$ ) but by elevated dissolved $\mathrm{NO}_{3}{ }^{-}$and $\mathrm{Cl}^{-}$. The abundance of major ions (especially $\mathrm{NO}_{3}{ }^{-}, \mathrm{Cl}^{-}$and $\mathrm{SO}_{4}{ }^{2-}$ ) suggests alteration of the physical-chemical properties of fresh water resources. In particular, such high values of $\mathrm{NO}_{3}{ }^{-}$, up to $208 \mathrm{mg} \mathrm{L}^{-1}$ in $\mathrm{P} 8$, can pose serious risks to the health of the local population, because of the consumption of well water for domestic use (e.g. drinking and cooking).

The two spring samples, $\mathrm{S} 1$ and $\mathrm{S} 2$, show lower $\mathrm{Na}$ and $\mathrm{Cl}^{-}$concentrations (324-696 mg $\mathrm{L}^{-1}$ and 2141-4834 $\mathrm{mg} \mathrm{L}^{-1}$, respectively) but the presence of dissolved $\mathrm{NO}_{3}^{-}\left(68-96 \mathrm{mg} \mathrm{L}^{-1}\right)$.

With regard to trace elements, $\mathrm{Li}$ is the least abundant element, with values ranging from 0.01 to $0.23 \mathrm{mg} \mathrm{L}^{-1}$. All the wells show values of B largely exceeding the WHO drinking water limit $\left(0.5 \mathrm{mg} \mathrm{L}^{-1}\right)$, confirming the high salinization of the aquifer.

The $\delta^{15} \mathrm{~N}_{\text {-NO3 }}$ values (Table 3 ) vary from approximately +4 to $+13 \%$, and are in the range of signatures for soil organic matter, manure and septic systems (Kendall, 1998). The $\delta{ }^{18} \mathrm{O}$. 
NO3 varies between +8 to $+18 \%$. The mean value for $\delta^{13} \mathrm{C}$ of DIC is $-8.8 \%{ }^{\circ} \pm 2.6$, while the mean $\delta^{18} \mathrm{O}$ and $\delta^{2} \mathrm{H}$ are $-5.1 \%{ }^{\circ} \pm 0.2$ and $-36.7 \%{ }^{\circ} \pm 1.8$, respectively.

\subsection{Lagoon water}

Lagoon water temperature mainly reflects air temperature, with an average value of 26.5 ${ }^{\circ} \mathrm{C}$. This is mainly due to the fact that only surface water samples were collected. Values of $\mathrm{pH}$ are in the range of marine waters, ranging from 7.5 to 8.5 (average 8.2). Most of the lagoon water samples have conductivity values of about $55.00 \mathrm{mS} \mathrm{cm}{ }^{-1}$, with a maximum of $55.70 \mathrm{mS} \mathrm{cm}^{-1}$ in L4. Neither major nor trace elements show significant variations among the different sampling stations, and the same behaviour is shown for the isotopic signal of ${ }^{18} \mathrm{O}$, whose mean value is $1.15 \% \%_{0} \pm 0.05$.

\section{Discussion}

\subsection{Groundwater recharge}

In order to define the main sources of recharge, the isotopic composition of the water molecule $\left(\delta^{18} \mathrm{O}\right.$ and $\left.\delta^{2} \mathrm{H}\right)$ for groundwater sampled in the Bou-Areg plain was compared with the Global Meteoric Water Line (Fig. 4. GMWL: $\delta^{2} \mathrm{H}=8.17 \delta^{18} \mathrm{O}+10.35$; Rozanski et al., 1993). Since rain and river water specifically belonging to the investigated area are not presently available, the following were used:

- the Western Mediterranean Meteoric Water Line (WMMWL) $\delta^{2} \mathrm{H}=8 \delta^{18} \mathrm{O}+14$ (Celle, 2000) which is influenced by both Oceanic and Mediterranean air masses, as reference for the isotopic composition of precipitation, and

- the Tafna river basin in central Algeria, located about $200 \mathrm{~km}$ E of Nador, with comparable geographical settings, as reference for the isotopic composition of surface water $\left(\delta^{2} \mathrm{H}=6.18 \delta^{18} \mathrm{O}-2.26\right.$; Lambs and Labiod, 2009).

Figure 4 shows that for both surveys groundwater in the Bou-Areg aquifer plots below the GMWL and the WMMWL, following a regression line of equation $\delta^{2} \mathrm{H}=6.72 \delta^{18} \mathrm{O}-0.95$ in November 2009 and $\delta^{2} \mathrm{H}=6.71 \delta^{18} \mathrm{O}-2.70$ in June 2010.

The observed slope of about 6.7 could be due to the occurrence of evaporative loss prior to recharge (Clark and Fritz, 1997). When evaporation occurs, the heavy isotope enrichment ratio $\delta^{2} \mathrm{H} / \delta^{18} \mathrm{O}$ follows a slope of about 5 (Craig, 1961), but ranging from 3.9 to 6.8 , largely depending on relative humidity (Gonfiantini, 1986). In the present case, values could suggest the occurrence of evaporation with high relative humidity. Nevertheless, despite the strong evaporation characterizing arid and semi-arid regions, it is possible that newly formed groundwater has isotope content close to the mean composition of precipitation (Clark and Fritz, 1997). In this case, although evaporation may to some extent contribute, other processes, such as water-rock interaction, mineral dissolution or mixing processes might be the main factors controlling the isotopic composition. However, the lack of precipitation data in the region, do not allow assessing the extent of evaporative processes.

The deviation, even from the WMMWL (Celle, 2000), could possibly be due to a contribution of continentally driven precipitation to recharge. In this regard, it should be noted that the equation describing the isotopic composition of the Tafna river, originating in the Algerian Atlas, also shows a similar slope. The comparison would support the theory that natural recharge for the Bou-Areg aquifer could be due to runoff from the Atlas chain and runoff from the surrounding relief (Chaouni Alia et al., 1997). Wells 5 and 5b, although not showing the same depleted isotopic fingerprint, could be representative of this recharge. Indeed these two wells are located at the boundary of the irrigated area (Fig. 3) and are relatively deep (Table. 1). In addition, the wells are separated from the whole system by a flexure, parallel to the lagoon (Bloundi, 2005), acting as hydraulic barrier, thus limiting exchange with the Bou-Areg system. The low redox potential and low TDS could indicate that these wells represent the recharge coming from the peripheral areas of the Bou-Areg 
plain and, therefore, not affected by human pollution or water-rock interaction with the carbonate system (see following sections).

Another possible cause of deviation towards more enriched values could be mixing with external saline sources. In this case $\delta^{18} \mathrm{O}$ and $\delta^{2} \mathrm{H}$ values would deviate from GMWL and WMMWL, towards elevated $\delta^{18} \mathrm{O}$ and $\delta^{2} \mathrm{H}$ values (and with lower $\delta^{2} \mathrm{H} / \delta^{18} \mathrm{O}$ slope), as observed in the Bou-Areg aquifer. In arid and semiarid environments, irrigation water infiltrating aquifers is generally characterized by the concomitant presence of the two processes: subsurface evaporation and leaching of soil saline content (e.g. Ben Moussa et al., 2011). By comparing the $\delta^{18} \mathrm{O}$ composition with $\mathrm{Cl}^{-}$and $\mathrm{NO}_{3}{ }^{-}$concentrations, some groundwater samples are shown to have high $\mathrm{Cl}^{-}\left(>1000 \mathrm{mg} \mathrm{L}^{-1}\right)$ and $\mathrm{NO}_{3}^{-}\left(>50 \mathrm{mg} \mathrm{L}^{-1}\right)$ concentrations associated with relatively high $\delta^{18} \mathrm{O}$ values (Fig. 5). This association suggests that agricultural return flow could be another important recharge source in the aquifer (Ahkouk et al., 2003; Bouchaou et al., 2008). On the other hand, wells with relatively higher $\delta^{18} \mathrm{O}$ values and lower $\mathrm{Cl}^{-}$concentrations may be the result of mixing with an already evaporated freshwater end-member (e.g. irrigation channel water).

Close to the Selouane oued, some sampled wells could also be affected by local recharge. For example wells $7 \mathrm{~b}, 18$ and 30 , all located on the left bank of the river and quite close to each other (Fig. 3), show depleted isotopic compositions suggesting possible groundwater recharge by river water in the area. Well 30 is the deepest of the three, showing a more depleted $\delta^{18} \mathrm{O}$ signal $(-4.98 \%)$. On the other hand well $7 \mathrm{~b}$ has high EC $\left(9.1 \mathrm{~ms} \mathrm{~cm}^{-1}\right), \mathrm{Cl}^{-}$ concentration $\left(2525.2 \mathrm{mg} \mathrm{L}^{-1}\right)$ and $\delta^{18} \mathrm{O}$ composition of $-4.94 \%$, while well 18 has the most enriched signal for both $\delta^{2} \mathrm{H}$ and $\delta^{18} \mathrm{O}$. These discrepancies could be associated with different local recharge processes possibly interacting with the common effect of agricultural inputs.

Therefore, the preliminary investigation on stable isotope composition, allowed to evidence the presence of two main sources of groundwater recharge, corresponding to different recharge processes: (i) underground flow from the mountain front, resulting in groundwater with relatively good quality, mainly tapped in the south-eastern part of the aquifer and (ii) local infiltration and agricultural return flow, affecting groundwater located in the central part of the Bou-Areg plain.

\subsection{Groundwater salinity}

Groundwater salinity is determined by the Total Dissolved Solids (TDS), a parameter that can be calculated from the sum of major ions. None of the samples collected in the November field investigation can be classified as freshwater (TDS $<500 \mathrm{mg} \mathrm{L}^{-1}$ ), and all are considered as brackish waters (Custodio and Llamas, 1976; Castany, 1982). An increase in mineralization in June 2010, with respect to November 2009, is observed for all the wells. This could be associated with increased dissolution of minerals occurring in the unsaturated zone, thus recharging the underground system with more dissolved salts (Allison et al., 1994), in response to seasonal fluctuations of climatic parameters.

In the plot of $\mathrm{Na}^{+}$concentration versus $\mathrm{Cl}^{-}$concentration (Fig. 6A), a few samples (3, 4, 12, 24 and 29) have compositions in agreement with progressive dilution with seawater, thus suggesting that their composition is dominantly governed by mixing between seawater or connate water with the recent recharge in this sector of the aquifer (Chaouni Alia et al., 1997; El Yaouti et al., 2009). No correlation was observed between $\mathrm{Cl}^{-}$or $\mathrm{Na}^{+}$content and the depth of the wells or their proximity to the coast. In addition hydraulic heads (Fig. 2, profile 1) are incompatible with sea water intrusion far inland.

The majority of the samples plot above the freshwater-seawater dilution line. This enrichment in $\mathrm{Na}^{+}$could indicate the presence of water-aquifer interactions, and cation exchange reactions between the silicate fractions of the aquifer and groundwater rich in dissolved calcium. Therefore, as a first approximation, it could be assumed that the circulation is slow, facilitating exchange with silicates, with the liberation of $\mathrm{Na}^{+}$exchanged for $\mathrm{Ca}^{2+}(\mathrm{El}$ Yaouti et al., 2009). 
Nevertheless, by plotting $\mathrm{Ca}^{2+}$ versus $\mathrm{Cl}^{-}$, (Fig. 6B) an excess in $\mathrm{Ca}^{2+}$, with respect to the seawater dilution trend, is also observed. This $\mathrm{Ca}^{2+}$ could originate from dissolution of carbonates or gypsum. Moreover, $\mathrm{Li}$ and $\mathrm{Sr}$ (Table 2) show a good correlation with $\mathrm{Ca}^{2+}$ $\left(\mathrm{R}^{2}=0.50\right.$ and $\mathrm{R}^{2}=0.57$, respectively; $\mathrm{n}=30$ in June 2010), thus confirming the likely occurrence of those processes. Dissolution would occur when rainwater or irrigation water, entering the aquifer, dissolves carbonate rocks, and could be confirmed by the high $\mathrm{HCO}_{3}{ }^{-}$ concentrations throughout the aquifer (ranging from 318 to $840 \mathrm{mg} \mathrm{L}^{-1}$ ). On the other hand, $\mathrm{SO}_{4}{ }^{2-}$ concentrations are also high (ranging from 385 to $1097 \mathrm{mg} \mathrm{L}^{-1}$ ), but do not show a 1:1 molar ratio with $\mathrm{Ca}^{2+}$.

To evidence the possible occurrence of saline/lagoon water intrusion, the $\mathrm{Cl} / \mathrm{Br}$ ratio was also studied and compared with the $\mathrm{Cl} / \mathrm{Na}$ ratio (Fig. 7A). Given the conservative nature of $\mathrm{Cl}^{-}$ , $\mathrm{Cl} / \mathrm{Br}$ and $\mathrm{Cl} / \mathrm{Na}$ ratios variations can in fact be attributed to bio-geochemical processes occurring within the aquifer. In particular, $\mathrm{Br}^{-}$might be released during organic matter degradation and adsorbed due to biological processes (Putschew et al., 2003), the latter resulting in increasing $\mathrm{Cl} / \mathrm{Br}$ ratios. On the other hand, $\mathrm{NaCl}$ is widely used in different anthropogenic activities, and a high $\mathrm{Cl} / \mathrm{Br}$ ratio is generally considered a good indicator for the impact of domestic wastewater (Vengosh and Pankratov, 1998). An enrichment in Na may indicate $\mathrm{Ca}-\mathrm{Na}$ exchange occurring during aquifer refreshening; a depletion in $\mathrm{Na}$ and a correspondent increase in $\mathrm{Ca}$ in the solution would instead occur during sea water intrusion, as previously described.

Most of the samples collected in the Bou-Areg aquifer, in both November 2009 and June 2010 show $\mathrm{Na} / \mathrm{Cl}$ ratios lower than seawater and $\mathrm{Cl} / \mathrm{Br}$ ratios higher than seawater. These ratios might both be influenced by an overall enrichment in $\mathrm{Cl}^{-}$in solution.

Only a few samples (mostly from the June 2010 campaign, such as 7b, 19, 20, 21, 22, 27) are characterized by a high $\mathrm{Na} / \mathrm{Cl}$ (e.g. $\mathrm{Na}$ excess), potentially attributed to saline water intrusion. However, the fact that all the samples are located in the Selouane corridor (and along the sides of the Selouaneoued), raises some concerns on the possible impact of the river, or groundwater from the Gareb Plain, on aquifer salinization. Indeed, the Gareb Plain groundwater is characterized by high concentrations of $\mathrm{Cl}^{-}, \mathrm{SO}^{2-}, \mathrm{Na}^{+}, \mathrm{Mg}^{2+}, \mathrm{Ca}^{2+}$ (El Yaouti et al., 2008) and a salinity even higher than groundwater from the Bou Areg aquifer. Further investigation on the chemical and isotopic composition of Selouane oued waters is required to support this interpretation.

The correlation diagram between $[(\mathrm{Na}+\mathrm{K})-\mathrm{Cl}]$ and $\left[(\mathrm{Ca}+\mathrm{Mg})-\left(\mathrm{HCO}_{3}-\mathrm{SO}_{4}\right)\right]$ also supports the possible occurrence of cation-exchange processes, in addition to carbonate dissolution, as the samples plot coherently with the -1:-1 line (Fig. 7B). In addition, all the samples plot slightly below the -1:-1 line, highlighting the general enrichment in $\mathrm{Cl}^{-}$. In the absence of clear geochemical evidence of sea water intrusion, this $\mathrm{Cl}$ - excess is possibly due to pollution (see following section).

To confirm the proposed hypotheses for salinization, Saturation Indices for calcite, dolomite, gypsum and aragonite have been calculated and plotted versus Total Dissolved Solids (Fig. 8). Almost all groundwater samples appear to be supersaturated with respect to calcite, dolomite and aragonite, suggesting that those minerals are present in the host rocks or in the unsaturated zone. The presence of limestone in the aquifer deposits and the existence of calcite and dolomite detected by X-ray diffraction (Mahjoubi et al., 2003; Bloundi, 2005) could lead, as also proposed by El Yaouti et al. (2009), to an increase in $\mathrm{Ca}^{2+}, \mathrm{Mg}^{2+}$ and $\mathrm{HCO}_{3}{ }^{-}$concentrations in the aquifer, when carbonates are dissolved. On the other hand, all the samples appear to be undersaturated with respect to gypsum, suggesting that evaporitic mineral phases are minor or absent in the host rock (Bloundi et al., 2005).

In summary, the high groundwater salinity is attributed to water-rock interaction processes such as dissolution of carbonates, contained in the unsaturated zone and in the aquifer matrix, and cation exchange with silicates. According to the data, sea water intrusion is limited to an area of the aquifer, as also indicated by El Yaouti et al. (2009). 


\subsection{Evaluation of human induced pollution: Nitrates in Groundwater}

The main anthropogenic activities in the investigated area are associated with agricultural practices and urban (or rural) development, sometimes characterised by inadequate sanitation systems. This causes $\mathrm{NO}_{3}{ }^{-}$pollution leading to concentrations often exceeding the Moroccan drinking water standard (40 mg L${ }^{-1}$, El Yaouti et al., 2009). In particular, in the case of the June 2010 survey only 3 wells $(2,5$ b and 23$)$ are within the drinking standard limits, although wells $3,12,13$ and 15 are also below the WHO limit of $50 \mathrm{mg} \mathrm{L}^{-1}$ (WHO, 2006). Therefore, it is of paramount importance to clearly identify the sources of dissolved $\mathrm{NO}_{3}{ }^{-}$in the investigated area to prevent the aquifer from further contamination and reduce the risks associated with public health.

The distribution map of dissolved $\mathrm{NO}_{3}{ }^{-}$for the June 2010 campaign (Fig. 9) shows that the highest concentrations occur in the centre of the plain (agricultural zone, e.g. wells P28, $\mathrm{P} 1, \mathrm{P} 11)$ and in the urban area (P8 in Taouima and P9 in Nador).

Figure 6A shows that some wells, plotting below the sea-water dilution line, show an increase in $\mathrm{Cl}^{-}$concentration that could be indicative of pollution loads. The same enrichment in $\mathrm{Cl}^{-}$is evident in Figure 10A, associated with an increase in dissolved $\mathrm{NO}_{3}{ }^{-}$(Group B, e.g. wells 4, 7b, 27 and 30). This coupled increase can be attributed to agricultural pollution. Indeed, Figure 10C shows that wells of Group B are also affected by a K enrichment that can be expected in groundwater recharged by infiltration from cultivated areas, as a consequence of nutrient leaching (Griffioen, 2001).

Higher values for the June 2010 survey could be indicative of the aforementioned local recharge and attributed to leaching trough the unsaturated zone after the rainy season, allowing for the remobilization of pollutants.

In Figure 10A, a second group of samples (group A) can be highlighted, showing relatively low $\mathrm{Cl}^{-}$concentrations ( $\sim 1000 \mathrm{mg} \mathrm{L}^{-1}$, e.g wells 1,9 and 8$)$ but strongly enriched in $\mathrm{NO}_{3}{ }^{-}$. These samples could be affected by an input of manure-derived $\mathrm{NO}_{3}{ }^{-}$or septic effluents. Low $\mathrm{K}$ values (Fig. 10C) may confirm the absence of (or very low) agricultural inputs for those wells. The same trends are also identified in literature data (Fig. 10B, D). Also, a third group of samples appears in the literature data with high $\mathrm{Cl}^{-}$contents and low $\mathrm{NO}_{3}{ }^{-}$(Fig. 10B); these are located in a specific area of the aquifer and attributed by the authors to seawater intrusion (El Yaouti et al., 2009).

$\delta^{13} \mathrm{C}$ was studied in order to better understand the sources of pollution in the aquifer and the associated recharge processes. Indeed, in groundwater, the $\delta^{13} \mathrm{C}$ depends on the level of $\mathrm{CO}_{2}$ in the soil and the possible interaction of photosynthetic uptake (fixation of $\mathrm{CO}_{2}$ by $\mathrm{C} 3$ or $\mathrm{C} 4$ plants). When infiltrating water interacts with carbonates in the unsaturated zone and in the aquifer, the $\delta^{13} \mathrm{C}_{\mathrm{DIC}}$ will evolve towards more enriched values. On the other hand, decomposition of organic matter and organic pollutants generally cause an isotopic depletion (Clark and Fritz, 1997).

By comparing ${ }^{13} \mathrm{C}$ and ${ }^{18} \mathrm{O}$ (Fig. 11), the isotopic composition of $\mathrm{O}$ appears more uniform, indicating that the waters are affected by the same fractionation processes (evaporation in the aquifer, evaporation during irrigation and water recycling), whereas the $\mathrm{C}$ isotopic composition is more variable.

Wells of the previously identified Group A have a more negative $\delta^{13} \mathrm{C}$ composition, typical of local recharge remobilizing pollutants in the unsaturated zone, and causing changes in the isotopic composition of ${ }^{13} \mathrm{C}$. On the other hand, well $5 \mathrm{~b}$ has a deep recharge signal, and hence of water circulating in a system without interaction with secondary minerals precipitated in the unsaturated zone, supporting the interpretation proposed in the previous section. In group $\mathrm{B}$, the more depleted values could correspond to dissolution of $\mathrm{CO}_{2}$ from soils cultivated with $\mathrm{C} 4$ plants (e.g. common agricultural crops, corn and sorghum), having a $\delta^{13} \mathrm{C}$ ranging from -10 to $-16 \%$. Also, a tendency towards more positive ${ }^{13} \mathrm{C}$ values can be observed, which could be ascribed to carbonate dissolution $\left(\delta^{13} \mathrm{C}\right.$ of marine carbonate $\sim 0 \%$ ) in intensively irrigated areas. 
The isotopic composition of $\delta^{15} \mathrm{~N}_{\mathrm{NO} 3}$ and $\delta^{18} \mathrm{O}_{\mathrm{NO} 3}$ was investigated to clarify the origin of $\mathrm{NO}_{3}{ }^{-}$in the system. By comparing the obtained isotopic data for groundwater in the Bou-Areg aquifer (Fig. 12), with the isotopic composition of $\delta^{15} \mathrm{~N}_{\mathrm{NO} 3}$ in manure, septic system effluents $(10-15 \%)$ in soil organic matter $(\sim 5 \%)$ and fertilizers $(\sim 0 \%$; Clark and Fritz, 1997$)$ two main sources of $\mathrm{N}$ input to groundwater can be distinguished. Two wells, located in the suburbs of the city of Nador, and showing the highest dissolved $\mathrm{NO}_{3}{ }^{-}$concentrations, appear to be clearly affected by pollution from manure and septic effluent systems $(\sim+12 \%)$, while two others, located in the central part of the plain, point to an input of mineral fertilizers ( $+4 \%$ ), in agreement with their high $\mathrm{K}$ concentrations. As a general feature, most of the wells appear to be a mixing between these two main sources. Indeed, although their isotopic composition falls in the compositional field of soil organic matter $\left(\delta^{15} \mathrm{~N} \sim+4\right.$ to $+10 \%$, a mixed origin is more compatible with their $\mathrm{NO}_{3}{ }^{-}$content, greatly exceeding $50 \mathrm{mg} \mathrm{L}^{-1}$ (Clark and Fritz, 1997). The same $\mathrm{NO}_{3}{ }^{-}$sources may be evoked for both springs.

With regard to $\delta^{18} \mathrm{O}_{\mathrm{NO} 3}$, most of the samples appear to be in equilibrium with the isotopic composition of the water molecule $\left(\delta^{18} \mathrm{O}_{\mathrm{H} 2 \mathrm{O}} \sim-4 \%\right.$ ). Very few samples show an isotopic composition of $\mathrm{NO}_{3}^{-}$enriched in both isotopes, testifying for the absence of strong denitrification.

In summary, the high $\mathrm{NO}_{3}{ }^{-}$content is related to an input from agricultural return flow, also leaching soluble salts during its transit through the unsaturated zone, as described in the previous section, and to sewage leakage.

\subsection{Aquifer-lagoon interaction}

Due to the hypersaline nature of the lagoon, one can assume that there are three main processes controlling its chemical composition: (i) evaporation, (ii) inflow from agricultural sources and groundwater flow, discharging directly into the lagoon associated with (iii) the influence of seawater entering from the inlet (Fontes et al., 1985).

To confirm and define the occurrence of evaporation, chemical data were compared with the geochemical characteristics of partially evaporated marine water (Fontes and Matray, 1993; Conti et al., 2000) and major ions were plotted against $\mathrm{Cl}^{-}$(Fig. 13).

All the lagoon samples fall along the fresh water-sea water dilution trend, showing a $\mathrm{Na} / \mathrm{Cl}$ ratio in agreement with that of sea water (Fig. 13A). The excess in $\mathrm{Ca}$ for all the samples is also evident (Fig. 13B), shifting lagoon water samples towards the composition of sea-water at the beginning of calcite precipitation. The high $\mathrm{Ca}$ values represent the main peculiarity of the groundwater-lagoon water system. This Ca excess has also been observed by other authors (Bloundi, 2005; El Mandour et al., 2008; El Yaouti et al., 2009) and attributed to different processes such as calcite and gypsum dissolution. However the mechanism causing the enrichment in freshwater and its transfer to lagoon water, both in principle saturated with respect to calcite, needs further investigation.

The same behaviour can be observed for $\mathrm{SO}_{4}{ }^{2-}$ (Fig. 13C): in this plot, the composition of the two springs appears to be slightly below the mixing line.

Potassium variations in lagoon waters are observed for almost constant values of $\mathrm{Cl}^{-}$ (values coherent with the seawater one, Fig. 13D). The proposed continental water contribution to the lagoon and the associated impact of agricultural runoff is testified by the high content of spring waters discharging in the lagoon.

Comparing variations of $\mathrm{Br}^{-}$to $\mathrm{Cl}^{-}$, shows that lagoon samples have a geochemical composition in agreement with that of marine water (Fontes and Matray, 1993; Conti et al., 2000), with some samples slightly exceeding seawater concentrations. Spring samples S1 and S2 have concentrations characteristic of groundwater mixing with more saline (lagoon) water.

When considering the isotopic signature of the water molecule (Fig. 3), lagoon waters are quite homogeneously enriched in both ${ }^{18} \mathrm{O}$ and ${ }^{2} \mathrm{H}$ compared to seawater. This enrichment, associated with the deviation from the GMWL suggests the occurrence of evaporation. The isotopic signal of ${ }^{13} \mathrm{C}$ (Table 3 ) shows a tendency toward sea water composition $(+1 \%$ ), while S1 and S2 clearly show a signal that is not influenced by sea water mixing, thus 
confirming the continental origin of the waters, as the signal is more coherent with groundwater DIC of freshwater carbonates ( -13\%; Clark and Fritz, 1997). L17 (-6.84\%o) has a tendency towards seawater values as well, thus indicating a lower degree of water mixing in the port Sidi Ali area.

In the same way by comparing $\mathrm{Cl}^{-}$content and ${ }^{18} \mathrm{O}$ (Fig. 13F), these tendencies can be observed. In fact, the isotopic enrichment in ${ }^{18} \mathrm{O}$ is not associated with a change in $\mathrm{Cl}^{-}$ concentration, suggesting once again that the main active process involves evaporation of lagoon waters, whereas the net change in the mass of water may be less important (Baneschi, 2007). Figure $13 \mathrm{~F}$ also shows that most of the samples have an ${ }^{18} \mathrm{O}$ signal towards the beginning of calcite evaporation. In this regard an isotopic mass balance approach could be used to quantify evaporation and confirm this interpretation.

\section{Conclusions}

Hydrogeochemical investigation of groundwater samples collected in the Bou-Areg coastal aquifer highlighted that the aquifer is characterized by two kinds of water: (i) freshwater, separated from the whole system and located at the limit of the irrigated area, characterized by low TDS, depleted isotopic composition and relatively high quality; and (ii)water mainly recharged by mountain runoff, interacting with local recharge, and acquiring salinity from different sources, thus creating a complex system of diluted waters.

Hydrochemical results confirm that the high salinity of the aquifer is caused by the coexistence of dissolution processes of evaporative rocks and carbonates from Miocene substrata, water-rock interaction, and human impacts due to agricultural return flows. The latter represents the main contribution to groundwater salinization, especially in the central part of the aquifer, as well as one of the main causes of the general increase in $\mathrm{NO}_{3}{ }^{-}$ concentrations. Locally, in the southern part of the aquifer, close to the city of Kariat Arkmane, the high salinization observed may be attributed to the presence of lagoon water intrusion (Chaouni Alia et al,, 1997).

Isotopic investigation on dissolved $\mathrm{NO}_{3}{ }^{-}$allowed identification of two main drivers for human induced pollution: (i) manure and septic effluents, especially in urban areas and in the central part of the plain where houses are not adequately equipped with sanitation systems, and (ii) synthetic fertilizers in the agricultural zone.

The study shows that agricultural return flow has significantly modified the chemistry of the system and is a prime example of human-induced changes in coastal environments.

Hydrogeochemical investigation allowed considering saline water intrusion from the lagoon to the shallow aquifer as negligible, while discharge of polluted groundwater into the lagoon has been found to partially alter its quality. As many springs are present on the lagoon shore, further studies should be extended to the evaluation and quantification of Submarine Groundwater Discharge (SGD) in order to better assess the impact of the aquifer on the lagoon.

\section{Acknowledgments}

This study was partially supported by the Italian Ministry for Environment, Land and Sea as a contribution to the GEF UNEP/MAP Strategic Partnership for Mediterranean Sea Large Marine Ecosystem (MedPartnership) under the sub-component executed by UNESCO-IHP on the "Management of Coastal Aquifer and Groundwater". The authors would like to thank Dr. Andrea Merla for the support provided during the whole project. We thank Dr. Mauro Brilli, Dr. Ilaria Baneschi, Dr. Enrico Allais and ISO4 s.n.c., for their help in the chemical and isotope analysis, and Ms. Ros Wright for the English revision of the manuscript. The authors would like to thank the two anonymous reviewers, the guest and the executive editors for their constructive remarks.

\section{References}

Abiodun, J. O., 1997. The challenges of growth and development in Metropolitan Lagos. In: 
Rakodi, C. (Ed.), The Urban Challenge in Africa: Growth and Management of its Largest Cities. Tokyo: United Nations University Press.

Ahkouk, S., Hsissou, H., Bouchaou, L., Krimissa, M., Mania, J., 2003. Impact des fertilisants agricoles et du mode d'irrigation sur la qualité des eaux souterraines (cas de la nappe des Chtoukas, bassin du Souss-Massa). Africa Geosci. Rev. 10, 355-364.

Akouvi, A., Dray, M., Violette, S., de Marsily, G., Zuppi, G. M., 2008. The sedimentary coastal basin of T ogo: example of a multilayered aquifer still influenced by a palaeoseawater intrusion. Hydrogeol. J. 16, 419-436.

Allison, G.B., Gee, G.W., Tyler, S.W., 1994. Vadose zone techniques for estimating groundwater recharge in arid and semiarid regions. Soil Sci. Soc. Am. J. 58, 6-14.

Art, H.W., Bormann, F.H., Voight, G.K., Woodwell, G.M., 1974. Barrier island forest ecosystem: role of meteorologic nutrient inputs. Science 184, 60-62.

Bakalowicz, M., 2006. Importance of regional study site conditions in elaborating concepts and approaches in karst science. In: Perspectives on karst geomorphology, hydrology, and geochemistry; a tribute volume to Derek C. Ford and William B. White. Geol. Soc. Am. Special Paper 404, 15-22.

Bakalowicz, M., Aunay, B., Le Strat, P., Dörfliger, N., Fleury, P., 2003. Karst development potential and base level changes in Mediterranean regions: a unique reference model. In: Tecnologìa de la intrusion de agua de mar en acuiferos costeros: paises mediterraneos. IGME, Madrid, ISBN. 84-7840, 470-478.

Baneschi, I., 2007. Geochemical and environmental study of a coastal ecosys tem: Massaciuccoli lake (northern Tuscany, Italy). PhD Thesis, Univ. "Ca' Foscari” of Venice, Dept. of Environmental Sciences, Venice, Italy.

Ben Moussa, A., Salem, S.B.H. Zouari, K., Marc, V., Jlassi, F., 2011. Investigation of groundwater mineralization in the Hammamet-Nabeul unconfined aquifer, north-eastern Tuni sia: geochemical and isotopic approach. Environ. Earth Sci. 62, 1287-1300.

Bloundi, M.K., 2005. Etude géochimique de la lagune de Nador- impacts des facteurs anthropiques. PhD Thesis, Sciences de la Terre et de l'Univers, Ecole et Observatoire des Sciences de la Terre Centre de Géochimie de la Surface (UMR 7517) et Université Mohamed V- Agdal Faculté des Sciences de Rabat UFR.. Océanolog-e -Géodynamique et Valorisation des Bassins sédimentaires.

Bouchaou, L., Michelot, J.L., Vengosh, A., Hsissou, Y., Qurtobi, M., Gaye, C.B., Bullen, T.D., Zuppi, G.M., 2008. Application of multiple isotopic and geochemical tracers for investigation of recharge, salinization, and residence time of water in the Souss-Massa aquifer, southwest of Morocco. J. Hydrol. 352, 267-287.

Brethes, J.C., Tesson, M., 1978. Observations hydrologiques sur la Sebkha Bou Areg (la lagune de Nador, Maroc). Bilan d'automne 76 et d'hiver 77. Bull. Institut Supérieur des Pêches Maritimes Maroc 24, 1-16.

Castany, G., 1982, Principes et méthodes d' l'hydrogéologie, Dunod, Paris

Chaouni Alia, A., Halimi, N. El., Walraevens, K., Beeuwsaert, E., De Breuck, W., 1997. Investigation de la salinisation de la plaine de Bou-Areg (Maroc nord-oriental). Proc. Reports International Association of Hydrological Sciences, Freshwater Contamination 243, 211-220.

Celle, H., 2000. Caractérisation des précipitations sur le pourtour de la Méditerranée occidentale. Approche isotopique et chimique, thèse, université d'Avignon.

Clark, I., Fritz, P., 1997. Environmental Isotopes in Hydrogeology. CRC Press.

Coleman, M.L., Sheppard, T.J., Durham, J.J., Rouse, J.E., Moore, G.R., 1982. Reduction of water with zinc for hydrogen isotope analysis. Anal. Chem. 54, 993-995.

Conti, A., Sacchi, E., Chiarle, M., Martinelli, G., Zuppi, G.M., 2000. Geochemistry of the formation waters in the Po plain (Northern Italy): an overview. Appl. Geochem. 15, 5165.

Craig, H., 1961. Isotopic variations in meteoric waters. Science 133, 1702-1703. 
Custodio, E., 2002. Aquifer overexploitation: what does it mean? Hydrogeol. J. 10, 254-277.

Custodio, E., 2004. Myths about seawater intrusion in coastal aquifers. Proc. $18^{\text {th }}$ Salt Water Intrusion Meeting, Cartagena, 599-608.

Custodio, E., Llamas, M.R. 1976. Hidrologia subterranea. Omega, Barcelona.

Di Sipio E., Malgaro A., Zuppi, G.M., 2006. New geophysical knowledge of groundwater systems in Venice estuarine environment. Estuar. Coast. Shelf Sci. 66, 6-12.

Edmunds, W.M., 2003. Renewable and non-renewable groundwater in semi-arid and arid regions. Devel. Water Sci. 50, 265-280.

Edmunds, W.M., Droubi, A., 1998. Groundwater salinity and environmental change. Isotope Techniques in the Study of Environmental Change, IAEA, Vienna, 503-518.

El Amrani, N., Benavente, J., El Mabrouki, K., Hidalgo, M.C., Larabi, A., 2005. Origine de la salinité des eaux au niveau de la plaine de Bou-Areg (Nador,Maroc). Bull. GFHN: Milieux poreux et transferts hydriques 51, 85-90.

El Mandour, A., El Yaouti, F., Fakir, Y., Zarhloule, Y., Benavente, Y., 2008. Evolution of groundwater salinity in the unconfined aquifer of Bou-Areg, Northeastern Mediterranean coast. Morocco. Environ. Geol. 54, 491-503.

El Yaouti, F., El Mandour, A., Khattach, D., Benavente, J., Kaufmann, O., 2009. Salinization processes in the unconfined aquifer of Bou-Areg (NE Morocco): A geostatistical, geochemical, and tomographic study. Appl. Geochem. 24, 16-31.

El Yaouti, F., El Mandour, A., Khattach, D., Kaufmann, O., 2008. Modelling groundwater flow and advective contaminant transport in the Bou-Areg unconfined aquifer (NE Morocco). J. Hydro-Environ. Res. 2, 192-209.

Epstein, S., Mayeda, T.K., 1953. Variation of O18 content of waters from natural sources. Geochim. Cosmochim. Acta 4, 213-224.

Fan, A.M., Steinberg, V.E. , 1996. Health Implications of Nitrate and Nitrite in Drinking Water: An Update on Methemoglobinemia Occurrence and Reproductive and Developmental Toxicity. Regulatory Toxicol. Pharmacol. 23, 35-43

Faye, S., Maloszewski, P., Stichler, W., Trimborn, P., Cissé, F. S., Gaye, C.B., 2005. Groundwater salinization in the Saloum (Senegal) delta aquifer: minor elements and isotopic indicators. Sci. Total Environ. 343, 243-259.

Food and Agriculture Organization, 2012. AQUASTAT, Global Map of Irrigation Areas Morocco. http://www.fao.org/nr/water/aquastat/irrigationmap/index30.stm (consulted online February 2012).

Fontes, J.C., Gasse, F., 1991. PALHYDAF (Paleohydrology in Africa) Program : objectives, methods, results. Palaeogeog. Palaeoclimatol. Palaeoecol. 84, 191-215.

Fontes, J.Ch., Matray, J.M., 1993. Geochemistry and origin of formation brines from the Paris basin, France. 1. Brines associated with Triassic salts. Chem. Geol. 109, 149-175.

Fontes, J. C., Gasse, F., Callot, Y., Plaziat, J. C., Carbonel,P., Dupeuble, P.A. and Kaczmarska, I., 1985. Freshwater to marine-like environments from Holocene lakes in northern Sahara. Nature 317, 608-610.

Gasse, F., Fontes, J.C., Plaziat, J.C., Carbonel, P., Kaczmarska, I., De Deckker, P., SouliéMarsche, I., Callot, Y., Dupeuple, P.A., 1987. Biological remains, geochemistry and stable isotopes for the reconstruction of environmental and hydrological changes in the Holocene lakes from North Sahara. Palaeogeog. Palaeoclimatol. Palaeoecol. 60, 1-46.

Gat, J.R., Naor Tahal H., 1979. The relationship between salinity and the recharge/discharge mechanism in arid lowlands. In: The hydrology of areas of low precipitation L'hydrologie des regions à faibles precipitations. Proc. Canberra Symp., December 1979; IAHS-AISH Publ. no. 128.

Giménez-Forcada, E., Bencini, A., Pranzini, G., 2009. Hydrogeochemical considerations 
about the origin of groundwater salinization in some coastal plains of Elba Island (Tuscany, Italy). Environ. Geochem. Health 32, 243-257.

Gonfiantini, R., 1978. Standards for stable isotope measurements in natural compounds. Nature 27, 534-536.

Gonfiantini. R., 1986. Environmental isotopes in lake studies. In: Fritz, P., Fonte,s J.-Ch., Handbook of Environmental Isotope Geochemistry, Vol. 2, The Terrestrial Environment, Elsevier, Amsterdam, 113-168.

Gonfiantini, R., Stichler, W., Rozanski, K., 1995. Standards and Intercomparison Materials Distributed by International Atomic Energy Agency for Stable Isotope Measurements: Reference and intercomparison materials for stable isotopes of light elements. Proc. consultants meeting held in Vienna, December 1993, IAEA Technical Document 825.

Gonzalez. I., Aguila. E., Galan. E., 2007. Partitioning, bioavailability and origin of heavy metals from the Nador Lagoon sediments (Morocco) as a basis for their management. Environ. Geol. 52, 1581-1593.

Green, T.R, , Taniguchi, M., Kooi, H., Gurdak, J.J, Allen, D.M., Hiscock, K.M., Treidel, H., Aureli, A., 2011. Beneath the surface of global change: Impacts of climate change on groundwater. J. Hydrol. 405, 532-560.

Griffioen, J., 2001. Potassium adsorption ratios as an indicator for the fate of agricultural potassium in groundwater. J. Hydrogeol. 254, 244-254.

Kendall, C., 1998. Tracing nitrogen sources and cycling in catchments. In: Kendall, C., McDonnell, J.J. (Eds), Isotope Tracers in Catchment Hydrology. Elsevier, Amsterdam, 519-576.

Kendall, C., Grim, E., 1990. Combustion tube method for measurement of nitrogen isotope ratios using calcium oxide for total removal of carbon dioxide and water. Anal. Chem. 62, 526-529.

Kroopnick, P., 1974. The dissolved O2 - CO2 - 13C system in the eastern equatorial Pacific. Deep Sea Res. 21, 211-227.

Lambs, L., Labiod, M., 2009. Climate change and water availability in north-west Algeria: investigation by stable water isotopes and dendrochronology. Water Internat. 34, 280-286.

Lenahan. M.J., Keith. L., Bristow. K.L., 2010. Understanding sub-surface solute distributions and salinization mechanisms in a tropical coastal floodplain groundwater system. J. Hydrol. 390, 131-142.

Llamas, M.R., Custodio, E., 2004. Intensive use of groundwater: challenges and opportunities. Taylor \& Francis, Rotterdam.

Mahjoubi. R., 2005. Sr isotopic tracing in a lagoonal system: example of surficial carbonate sediments in the Nador lagoon (North eastern Morocco). Bull. Société Géologique France 4, 373-380.

Mas-Pla, J., Bach, J., Vifals, E., Trilla, J., Estralrich, J., 1999. Salinization processes in a coastal leaky Aquifer system (Alt Empordà, NE Spain). Phys. Chem. Earth, Part B. Hydrol. Oceans Atmos. 24, 337-341.

Mazor, E., Molcho, M., 1972. Geochemical studies on the Feshcha Springs Dead Sea basin. J.Hydrol. 15, 37.

Oga Yei M.S., Sacchi, E., Zuppi, G.M., 2007. Origin and effects of nitrogen pollution in groundwater traced by $\delta 15 \mathrm{~N}-\mathrm{NO} 3$ AND $\delta 18 \mathrm{O}-\mathrm{NO} 3$ : the case of Abidjan (Ivory Coast). Internat. Symp. Advances in Isotope Hydrology and its role in Sustainable Water Resources Management. IAEA, Vienna 21-25 May 2007, IAEA-CN-151/31, vol. 1, 139147

Panno, S.V., Hackley, K.C., Hwang, H.H., Greenberg, S.E., Krapac, I.G., Landsberger, S., O'Kelly, D.J., 2006. Characterization and identification of $\mathrm{Na}-\mathrm{Cl}$ sources in ground water. Ground Water 44, 176-187. 
Putschew, A., Mania, M., Jekel, M., 2003. Occurrence and source of brominated organic compounds in surface waters. Chemosphere 52, 399-407.

Re, V., 2011. Groundwater in urban coastal areas: hydrogeochemical based approach for managing the transition areas: the example of the lagoon of Nador (Morocco). PhD Thesis Univ. Ca' Foscari of Venice, Italy.

Re, V., Zuppi, G.M., 2011. Influence of precipitation and deep saline groundwater on the hydrological systems of Mediterranean coastal plains: a general overview. Hydrolog. Sci. J. 56, 966-980.

Re, V., Cissé, Faye, S., Faye, A., Faye, S., Gaye, C.B., Sacchi, E., Zuppi, G.M., 2011. Water quality decline in coastal aquifers under anthropic pressure: the case of a suburbanarea od Dakar (Senegal). Environ. Monitor. Assess. 172, 605-622.

Rosenthal. E., Vinokurov. A., Ronen. D., Magaritz. M., Moshkovitz. S., 1992. Anthropogenically induced salinization of groundwater: A case study from the Coastal Plain aquifer of Israel. J. Contam. Hydrol. 11, 149-171.

Rozanski, K., Araguás-Araguás, L., Gonfiantini, R., 1993. Isotopic patterns in modern global precipitation. Geophysical Monograph 78, 1-36.

Sanchez-Martos, F., Pulido-Bosch, A., Molina-Sanchez, L., Vallejos-Izquierdo, A., 2002. Identification of the origin of salinization in groundwater using minor ions (Lower Andarax, Southeast Spain). Science Total Environ. 297, 43-58.

Sherif, M.M., Hamza, K.I., 2001. Mitigation of Seawater Intrusion by Pumping Brackish Water, Transport in Porous Media, 43, 1, 29-44, http://dx.doi.org/10.1023/A:1010601208708, DOI 10.1023/A:1010601208708.

Silva, S.R., Kendall, C., Wilkinson, D.H., Ziegler, A.C., Chang, C.C.Y., Avanzino, R.J., 2000. A new method for collection of nitrate from fresh water and the analysis of nitrogen and oxygen isotope ratios. J. Hydrol. 228, 22-36.

Tesson, M., 1977. Régime hydrologique et hydrodynamique de la sebkha Bou-Areg (lagune de Nador, Maroc). Bilan du printemps 1976. Bull. Institut Supérieur des Pêches Maritimes du Maroc 21.

Tesson, M., Gensous, R., 1981. Quelques caractères de la géochimie d'une lagune micro tidale: la sebkha de Bou-Areg (Maroc). Proc. $106^{\text {th }}$ Congres National des Sociétés Savantes Parpifnon Sciences 3, 183-194.

Trabelsi, R., 2009. Caracterisation hydrogeologique et geochimique du Systeme acquifere de la Djeffara (sud-est Tunisien): Modelisation et intrusion marinePhD Thesis, Ecole Nationale d'Ingénieurs de Sfax, Département de Génie Géologie, Sfax,Tunisia

Umgiesser, G., Chao, J., Bajo, M., Scroccaro, I., Cucco, A., 2005. Residence time modelling in the Nador Lagoon, Morocco. In: Proc. $1^{\text {st }}$ Internat. Conf. Coastal Conservation and Management in the Atlantic and Mediterranean, 389-397.

United Nations Environment Programme (UNEP), 2010. Strategic Partnership for the Mediterranean Sea Large Marine Ecosystem (MedPartnership). Inception Report, UNEP(DEPI)/MED WG.345/3.

Vanenschrick, G., van Wesemael, B, Frot, E, Pulido-Bosch, A., Molina, L., Stiévenard, M., Souchez, R., 2002. Using stable isotope analysis $(\delta \mathrm{D}-\delta 18 \mathrm{O})$ to characterize the regional hydrology of the Sierra de Gador, South East Spain. J. Hydrol., 265, 43 - 55.

Vengosh, A., 2003. Salinization and Saline Environments. In: Sherwood Lollar, B. (Ed.), Environmental Geochemistry. Holland, H.D., Turekian, K.T., Treatise on Geochemistry 9. Elsevier Science, 333-365.

Vengosh, A., Pankrato, I., 1998. Chloride/bromide and chloride fluoride ratios of domestic sewage effluents and associated contaminated ground water. Ground Water 36, 815-824.

Whipkey, C.E., Capo, R.C., Chadwick, O.A., Stewart, B.W., 2000. The importance of sea spray to the cation budget of a coastal Hawaiian soil: a strontium isotope approach. Chem. Geol. 168, 37-48.

Williams, W. D., 1999. Salinisation: A major threat to water resources in the arid and semi- 
arid regions of the world. Lakes Reservoirs: Res. Manage 4, 3/4, 85-91.

World Health Organization (WHO), 2006. Guidelines for Drinking-water Quality, ${ }^{\text {rd }}$ ed. $1^{\text {st }}$ Addendum to vol.1.

Zuppi, G.M., 2008. The groundwater challenge. In: Clini, C., Musu, I, Gullino, L.M. (Eds), Sustainable Development and Environmental Management Experience and Case Studies. Springer, 49-64. 


\section{Figure and table captions}

Figure 1. Location and geological setting of the studied area (Modified after El Yaouti et al., 2009).

Figure 2. Schematic hydrogeological profile of the Bou-Areg plain (Profile 1. Modified after El Yaouti et al., 2008) and cross section ( $\log 1)$ showing the four main formations identified in the investigated area (Modified after Chaouni Alia et al., 1997).

Figure 3. Location of the sample sites

Figure 4. Delta $\mathrm{D}$ and ${ }^{18} \mathrm{O}$ - variations in groundwater from the Bou-Areg coastal plain. Triangles indicate the isotopic composition of the two spring samples. Black dots correspond to the composition of lagoon water samples. Black and dashed grey lines represent the Global Meteoric Water Line (Rozanski et al., 1993) and the Western Mediterranean Meteoric Water Line (WMMWL) (Celle, 2000). The light grey dashed line depicts the Tafna river basin isotopic composition (Lambs and Labiod, 2009).

Figure 5. Variations of $\delta^{18} \mathrm{O}$ values (\%) versus $\mathrm{Cl}^{-}(\mathrm{A})$ and $\mathrm{NO}_{3}{ }^{-}(\mathrm{B})$ concentrations.

Figure 6. (A) Plots of Na versus $\mathrm{Cl}^{-}$and (B) Ca versus $\mathrm{Cl}^{-}$concentration (in $\mathrm{mmol} \mathrm{L}^{-1}$ ) for the samples collected in the Bou-Areg aquifer. The dashed grey line represents the seawater dilution trend.

Figure 7. (A) $\mathrm{Cl} / \mathrm{Na}$ with respect to $\mathrm{Cl} / \mathrm{Br}$ (molar ratio) compared to seawater ratio $(\mathrm{Cl} / \mathrm{Br}=655 ; \mathrm{Cl} / \mathrm{Na}=1.2)$. (B) Plot of $(\mathrm{Na}+\mathrm{K})-\mathrm{Cl}$ versus $\left[(\mathrm{Ca}+\mathrm{Mg})-\left(\mathrm{HCO}_{3}-\mathrm{SO}_{4}\right)\right]$ for the Bou-Areg Aquifer groundwater. The light green line represents the cation exchange line (1:-1), modified After Trabelsi, 2009.

Figure 8. Plot of saturation Index (SI) with respect to carbonates and gypsum calculated for the samples collected in the Bou-Areg aquifer in June 2010.

Figure 9. Distribution map of dissolved $\mathrm{NO}_{3}{ }^{-}\left(\mathrm{mgL}^{-1}\right)$ in the Bou-Areg Aquifer (June 2010). The interpolation was done without considering P10 (belonging to the Gareb Plain) and $\mathrm{P} 5 \mathrm{~b}$ (previously assumed to be separated from the system).

Figure 10. Plots of dissolved $\mathrm{NO}_{3}{ }^{-}$vs. $\mathrm{Cl}^{-}$: (A) Data for the November 2009 and June 2010 campaigns, (B) comparison with the available data on Bou-Areg Aquifer geochemistry: February 2004 (El Amrani et al., 2005), April 2004 (El Mandour et al., 2008) and December 2006 (El Yaouti et al., 2009); Plots of dissolved $\mathrm{NO}_{3}{ }^{-}$versus K: (C) Data for the November 2009 and June 2010 campaigns and (D) comparison with literature data. Dashed black line: Moroccan drinking water standard (El Yaouti et al., 2009).

Figure 11. Isotopic composition of groundwater in the Bou-Areg aquifer. Plot of ${ }^{13} \mathrm{C}(\%)$ versus ${ }^{18} \mathrm{O}(\%)$.

Figure 12. Isotopic composition of dissolved $\mathrm{NO}_{3}{ }^{-}(\%)$ for groundwater and spring water samples in the Bou-Areg aquifer (June 2010). Modified after Clark and Fritz (1997). Grayscale corresponds to $\mathrm{NO}_{3}{ }^{-}$concentrations. The position of the compositional fields is calculated for equilibrium with a $\delta^{18} \mathrm{O}_{\mathrm{H} 2 \mathrm{O}}$ of about $-4 \%$.

Figure 13. Chemical composition of Bou-Areg groundwater and Lagoon of Nador water. Major elements vs. $\mathrm{Cl}^{-}$concentration, logarithmic scale. (A) Na; (B) Ca; (C) $\mathrm{SO}_{4}{ }^{2-}$; (D) $\mathrm{K}$; (E) $\mathrm{Br}^{-}$; (F) ${ }^{18} \mathrm{O}$; a=seawater; $\mathrm{b}=$ beginning of calcite precipitation; $\mathrm{c}=$ beginning of gypsum precipitation; $d=$ beginning of halite precipitation; $\mathrm{e}=$ beginning of epsomite precipitation; $\mathrm{f}=$ beginning of sylvite precipitation; $\mathrm{g}=$ beginning of carnallite precipitation; $\mathrm{h}=$ =beginning of bischofite precipitation; dashed line=Sea Water Dilution Line (Fontes and Matray, 1993).

Table 1. Physicochemical parameters for samples collected in the Bou-Areg plain (November 2009 and June 2010).

Table 2. Chemical data (in $\mathrm{mgL}^{-1}$ ) for samples collected in the Bou-Areg plain (November 2009 and June 2010); ratios are expressed as molar ratio.

Table 3. Isotopic composition ( $\delta \%$ o) of groundwater in the Bou-Areg aquifer (November 2009 and June 2010). 


\begin{tabular}{|c|c|c|c|c|c|c|c|c|c|c|c|c|c|}
\hline Code & Nature & Sampling date & $\begin{array}{l}\text { Latitude } \\
\text { (degrees) }\end{array}$ & $\begin{array}{r}\begin{array}{c}\text { Longitude } \\
\text { (degrees) }\end{array} \\
\end{array}$ & $\begin{array}{c}\text { Altitude } \\
\text { (m) }\end{array}$ & $\begin{array}{l}\text { Air T } \\
\left({ }^{\circ} \mathrm{C}\right)\end{array}$ & $\begin{array}{l}\text { Depth } \\
\text { (m) }\end{array}$ & $\begin{array}{c}\text { Water T } \\
\left({ }^{\circ} \mathrm{C}\right)\end{array}$ & $\mathrm{pH}$ & $\begin{array}{c}\text { Conductivity } \\
\left(\mathrm{mSCm}^{-1}\right)\end{array}$ & $\begin{array}{c}\text { Eh } \\
(\mathrm{mV})\end{array}$ & $\begin{array}{c}\mathrm{CO}_{3}{ }^{2-} \\
\left(\mathrm{mgL}^{-1}\right)\end{array}$ & $\begin{array}{l}\mathrm{HCO}_{3} \\
\left(\mathrm{mgL}^{-1}\right)\end{array}$ \\
\hline P1 & Well & $26 / 11 / 2009$ & 35.0958 & -2.8543 & 20 & 20.4 & 5.90 & 18.3 & 8.21 & 3.4 & n.d & n.d & $\begin{array}{ll}\text { n.d } \\
\text { n. }\end{array}$ \\
\hline P2 & Well & $26 / 11 / 2009$ & 35.0928 & -2.8585 & 20 & 21.5 & 7.18 & 21.3 & 7.61 & 5.23 & n.d & n.d & n.d \\
\hline P3 & Well & $26 / 11 / 2009$ & 35.0978 & -2.7693 & 8 & 26.2 & 4.80 & 22.3 & 7.58 & 6.54 & n.d & n.d & n.d \\
\hline P4 & Well & $26 / 11 / 2009$ & 35.0958 & -2.7655 & 18 & 29.8 & 5.00 & 20.6 & 7.74 & 8.12 & n.d & n.d & n.d \\
\hline P5 & Well & $26 / 11 / 2009$ & 35.0835 & -2.7870 & 35 & 33.7 & 29.60 & 22.0 & 8.25 & 3.00 & n.d & n.d & n.d \\
\hline P6 & Well & $26 / 11 / 2009$ & 35.0889 & -2.8506 & 30 & 32.1 & 12.93 & 20.6 & 7.83 & 3.80 & n.d & n.d & n.d \\
\hline P7 & Well & $26 / 11 / 2009$ & 35.1070 & -2.8675 & 15 & 28 & 4.20 & 22.1 & 7.51 & 4.51 & n.d & n.d & n.d \\
\hline P8 & Well & $26 / 11 / 2009$ & 35.1305 & -2.9350 & 15 & 29.7 & 3.30 & 21.3 & 7.76 & 3.78 & n.d & n.d & n.d \\
\hline P9 & Well & 03/12/2009 & 35.1632 & -2.9189 & 4 & 18 & 2.50 & 21.6 & 7.35 & 3.20 & n.d & n.d & n.d \\
\hline P10 & Well & 03/12/2009 & 35.0642 & -2.9120 & 75 & 19 & 8.03 & 15.4 & 7.63 & 6.22 & n.d & n.d & n.d \\
\hline TAP & Tap & 03/12/2009 & 35.0958 & -2.8543 & - & - & - & 17.2 & 7.97 & 1.28 & n.d & n.d & n.d \\
\hline P1 & Well & 02/06/2010 & 35.0958 & -2.8543 & 20 & 29.9 & 5.90 & 19.7 & 7.83 & 4.80 & 150 & 27.0 & 720.0 \\
\hline P2 & Well & 02/06/2010 & 35.0928 & -2.8585 & 20 & 31.7 & 6.46 & 21.5 & 7.60 & 6.54 & 122 & 27.0 & 552.0 \\
\hline P3 & Well & $02 / 06 / 2010$ & 35.0978 & -2.7693 & 8 & 36.5 & 3.90 & 22.5 & 7.41 & 7.94 & 146 & 24.0 & 396.0 \\
\hline P4 & Well & 02/06/2010 & 35.0958 & -2.7655 & 18 & 37.6 & 4.30 & 21.6 & 7.43 & 10.52 & 153 & $<0.1$ & 438.0 \\
\hline P5 b & Well & $02 / 06 / 2010$ & 35.0772 & -2.8239 & 25 & 34.9 & 29.00 & 21.4 & 7.57 & 1.744 & -8 & 9.0 & 327.0 \\
\hline P6 b & Well & $02 / 06 / 2010$ & 35.1152 & -2.8957 & 22 & 36.8 & 3.50 & 21.5 & 7.32 & 8.25 & 190 & 6.0 & 366.0 \\
\hline P7 b & Well & $02 / 06 / 2010$ & 35.1203 & -2.9000 & 20 & 39.9 & 3.30 & 27.2 & 7.50 & 9.06 & 222 & 15.0 & 405.0 \\
\hline P8 & Well & $02 / 06 / 2010$ & 35.1305 & -2.9350 & 15 & 34.5 & 2.90 & 20.1 & 7.36 & 4.64 & 217. & 21.0 & 765.0 \\
\hline P9 & Well & $31 / 05 / 2010$ & 35.1632 & -2.9189 & 4 & 18 & 2.50 & 21.6 & 7.34 & 3.91 & 179. & 0.0 & 543.0 \\
\hline P10 & Well & $01 / 06 / 2010$ & 35.0642 & -2.9120 & 75 & 32.7 & 9.00 & 22.5 & 7.28 & 7.28 & 180. & 0.0 & 465.0 \\
\hline P11 & Well & $31 / 05 / 2010$ & 35.1035 & -2.8612 & 22 & 30.7 & 4.60 & 25.3 & 7.39 & 5.45 & 218 & 24.0 & 660.0 \\
\hline P12 & Well & $31 / 05 / 2010$ & 35.1024 & -2.8624 & 22 & 33.5 & 5.30 & 23.7 & 7.51 & 4.96 & 222 & $<0.1$ & 462.0 \\
\hline P13 & Well & $31 / 05 / 2010$ & 35.0995 & -2.8627 & 21 & 38 & 6.00 & 21.9 & 7.84 & 4.01 & 166 & 18.0 & 738.0 \\
\hline P14 & Well & $31 / 05 / 2010$ & 35.0944 & -2.8531 & 20 & 40 & 5.60 & 22.4 & 7.40 & 3.81 & 182 & $<0.1$ & 645.0 \\
\hline P15 & Well & $31 / 05 / 2010$ & 35.0974 & -2.7713 & 10 & 36.9 & 6.40 & 21.3 & 7.30 & 8.53 & 180 & $<0.1$ & 483.0 \\
\hline P16 & Well & $31 / 05 / 2010$ & 35.1020 & -2.8680 & 21 & 35.2 & 5.60 & 21.5 & 7.60 & 5.01 & 170 & $<0.1$ & 636.0 \\
\hline P17 & Well & $31 / 05 / 2010$ & 35.0999 & -2.8606 & 20 & 35.8 & 5.00 & 24.3 & 7.34 & 4.21 & 179 & $<0.1$ & 642.0 \\
\hline P18 & Well & $01 / 06 / 2010$ & 35.1176 & -2.9008 & 22 & 31 & 3.50 & 20.1 & 7.73 & 5.92 & 205 & $<0.1$ & 444.0 \\
\hline P19 & Well & $01 / 06 / 2010$ & 35.1047 & -2.8999 & 22 & 34.1 & 4.70 & 24.5 & 7.26 & 7.43 & 207 & $<0.1$ & 462.0 \\
\hline P20 & Well & $01 / 06 / 2010$ & 35.1041 & -2.9003 & 22 & 39.6 & 4.60 & 22.2 & 7.21 & 7.21 & 186 & $<0.1$ & 420.0 \\
\hline P21 & Well & $01 / 06 / 2010$ & 35.1067 & -2.8913 & 22 & 38 & 1.70 & 21.8 & 7.29 & 6.79 & 168 & $<0.1$ & 492.0 \\
\hline P22 & Well & $01 / 06 / 2010$ & 35.1044 & -2.8864 & 22 & 37.2 & 3.00 & 21.8 & 7.24 & 6.97 & 208 & $<0.1$ & 447.0 \\
\hline P23 & Well & $01 / 06 / 2010$ & 35.0976 & -2.8743 & 31 & 35.2 & 6.00 & 21.4 & 7.53 & 4.18 & 148 & $<0.1$ & 561.0 \\
\hline P24 & Well & $01 / 06 / 2010$ & 35.0927 & -2.8782 & 32 & 37.5 & 7.50 & 28.2 & 7.53 & 4.25 & 157 & 21.0 & 546.0 \\
\hline P25 & Well & $01 / 06 / 2010$ & 35.0841 & -2.8747 & 35 & 40.7 & 10.00 & 21.7 & 7.70 & 4.48 & 156 & 15.0 & 420.0 \\
\hline P26 & Well & $01 / 06 / 2010$ & 35.0805 & -2.8639 & 38 & 38 & 17.00 & 22.6 & 7.59 & 3.00 & 204 & 12.0 & 447.0 \\
\hline P27 & Well & $01 / 06 / 2010$ & 35.0822 & -2.9167 & 50 & 35.1 & 7.00 & 23.4 & 7.16 & 8.17 & 165 & 0.0 & 441.0 \\
\hline P28 & Well & 02/06/2010 & 35.1018 & -2.8523 & 26 & 33.6 & 3.40 & 20.6 & 7.85 & 5.59 & 160 & 30.0 & 840.0 \\
\hline P29 & Well & 02/06/2010 & 35.1245 & -2.8844 & 11 & 39.8 & 4.00 & 22.6 & 7.38 & 7.78 & 167 & $<0.1$ & 318.0 \\
\hline P30 & Well & 02/06/2010 & 35.1174 & -2.9039 & 21 & 40 & 5.00 & 22.1 & 7.24 & 6.70 & 152 & 21.0 & 474.0 \\
\hline L1 & Lagoon & 03/06/2010 & 35.1964 & -2.8834 & - & 34.7 & - & 27.6 & 8.25 & 55.00 & 190 & $<0.1$ & 176.9 \\
\hline L2 & Lagoon & 03/06/2010 & 35.2057 & -2.9072 & - & 33.3 & - & 27.1 & 8.35 & 55.30 & 178 & $<0.1$ & 204.4 \\
\hline L3 & Lagoon & 03/06/2010 & 35.2195 & -2.9086 & - & 33.0 & - & 26.7 & 8.39 & 55.50 & 163 & $<0.1$ & 186.1 \\
\hline L4 & Lagoon & 03/06/2010 & 35.2477 & -2.9276 & - & 32.4 & - & 27.0 & 8.40 & 55.70 & 163 & $<0.1$ & 180.0 \\
\hline L5 & Lagoon & 03/06/2010 & 35.1944 & -2.9250 & - & 32.1 & - & 27.6 & 8.47 & 55.10 & 165 & $<0.1$ & 176.9 \\
\hline L6 & Lagoon & 03/06/2010 & 35.1879 & -2.9242 & - & 31.9 & - & 27.1 & 8.50 & 55.10 & 158 & $<0.1$ & 180.0 \\
\hline L7 & Lagoon & $04 / 06 / 2010$ & 35.1664 & -2.9048 & - & 31.0 & - & 26.1 & 8.41 & 55.50 & 174 & $<0.1$ & 176.9 \\
\hline L8 & Lagoon & $04 / 06 / 2010$ & 35.1536 & -2.9011 & - & 31.7 & - & 26.0 & 8.30 & 55.00 & 149 & $<0.1$ & 186.1 \\
\hline L9 & Lagoon & 04/06/2010 & 35.1360 & -2.8817 & - & 31.7 & - & 25.6 & 8.26 & 54.90 & 138 & $<0.1$ & 186.1 \\
\hline L10 & Lagoon & 04/06/2010 & 35.1289 & -2.8683 & - & 30.9 & - & 25.4 & 8.25 & 54.90 & 125 & $<0.1$ & 183.0 \\
\hline L11 & Lagoon & 04/06/2010 & 35.1272 & -2.8586 & - & 30.6 & - & 25.3 & 8.31 & 55.10 & 138 & $<0.1$ & 180.0 \\
\hline L12 & Lagoon & 04/06/2010 & 35.1194 & -2.8461 & - & 29.7 & - & 25.1 & 8.25 & 55.10 & 134 & $<0.1$ & 173.9 \\
\hline L13 & Lagoon & $04 / 06 / 2010$ & 35.1286 & -2.8412 & - & 29.2 & - & 25.3 & 8.18 & 55.20 & 153 & $<0.1$ & 176.9 \\
\hline L14 & Lagoon & $04 / 06 / 2010$ & 35.1540 & -2.8631 & - & 28.6 & - & 25.2 & 8.20 & 55.20 & 120 & $<0.1$ & 176.9 \\
\hline L15 & Lagoon & 04/06/2010 & 35.1758 & -2.8842 & - & 28.2 & - & 25.9 & 8.16 & 55.30 & 90 & $<0.1$ & 173.9 \\
\hline L16 & Lagoon & 04/06/2010 & 35.1924 & -2.9112 & - & 29.2 & - & 27.3 & 8.18 & 55.30 & 96 & $<0.1$ & 176.9 \\
\hline L17 & Lagoon & 04/06/2010 & 35.1855 & -2.9244 & - & 30.1 & - & 30.4 & 8.11 & 49.70 & 123 & $<0.1$ & 216.6 \\
\hline L18 & Inlet & 06/06/2010 & 35.1940 & -2.8451 & - & 30.5 & . & 30.5 & 8.17 & 55.10 & 131 & $<0.1$ & 173.9 \\
\hline S1 & Source & 03/06/2010 & 35.2000 & -2.9198 & - & - & - & 24.7 & 7.84 & 7.94 & 182 & $<0.1$ & 387.4 \\
\hline S2 & Source & $04 / 06 / 2010$ & 35.1866 & -2.9249 & - & 32.6 & - & 25.0 & 7.50 & 15.66 & 150 & $<0.1$ & 372.1 \\
\hline
\end{tabular}

Table 1. Physicochemical parameters for the sampling collected in the Bou-Areg plain (November 2009 and June 2010). 


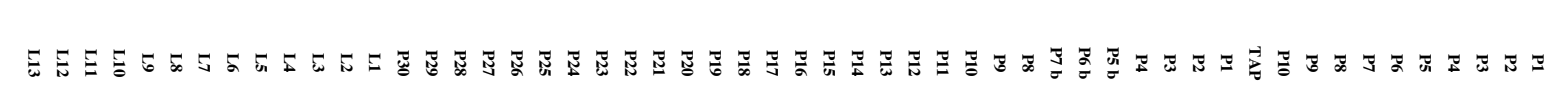

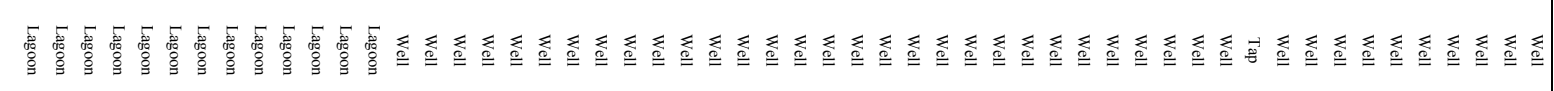

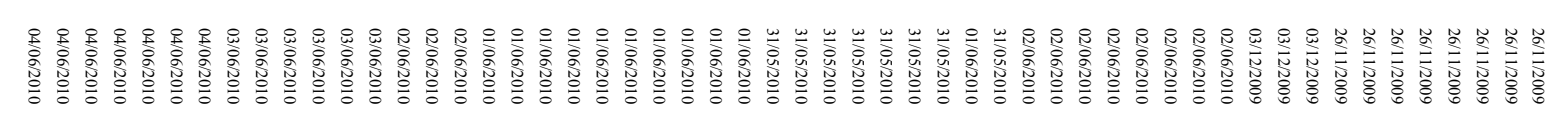

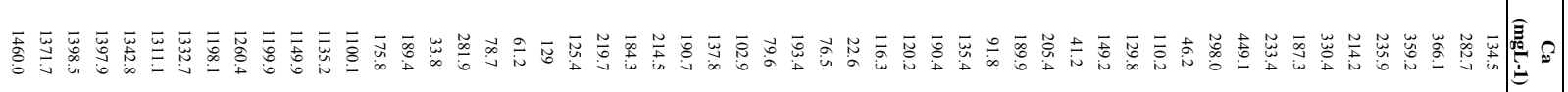

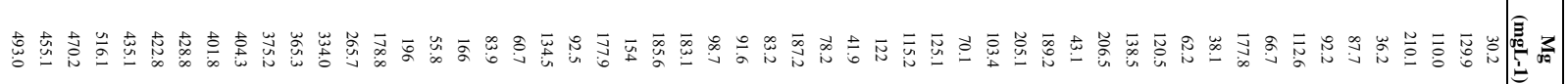

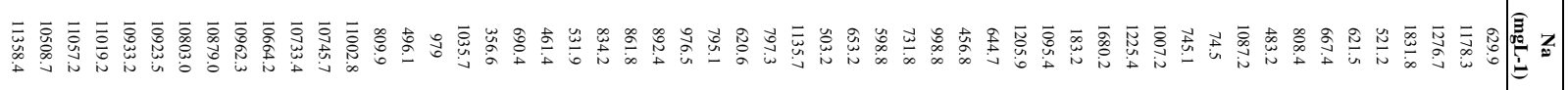

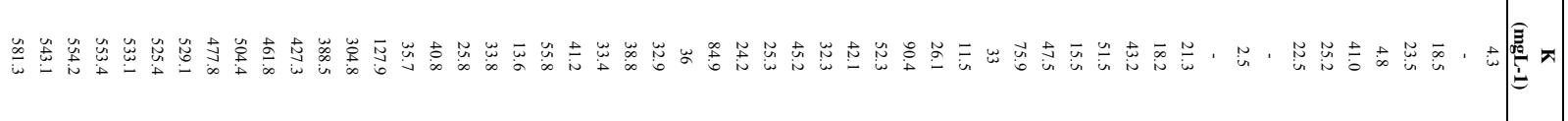

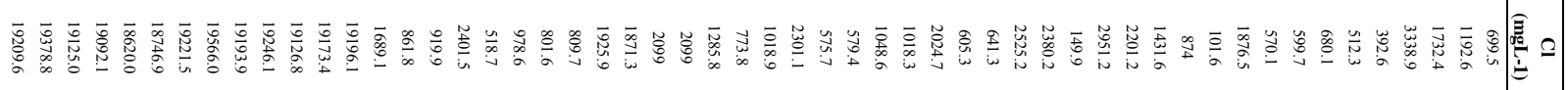

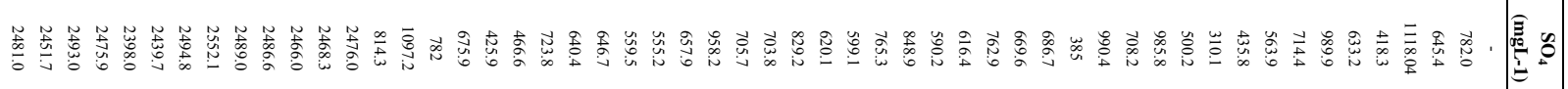

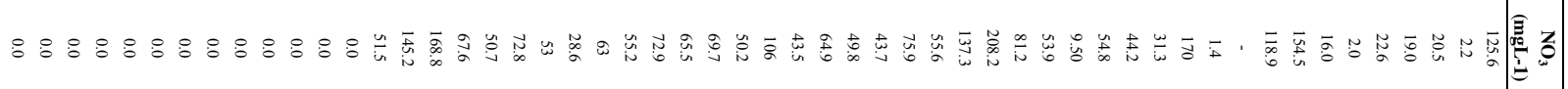

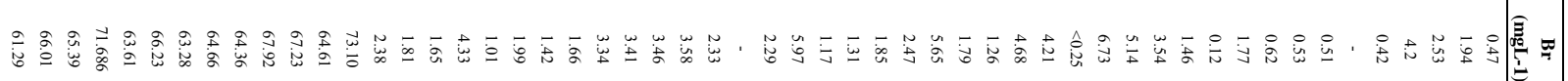

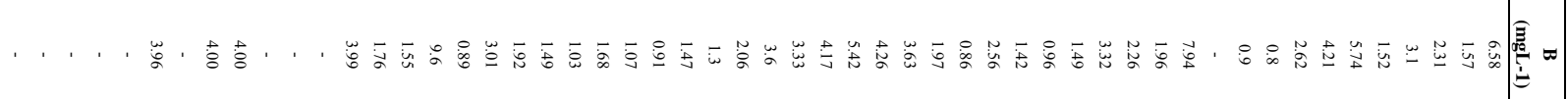
, . . . , 它. . . . . . . 는.

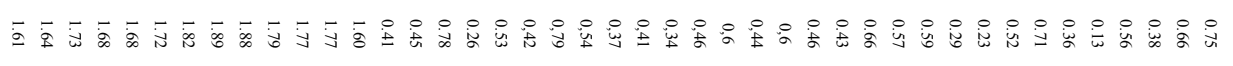

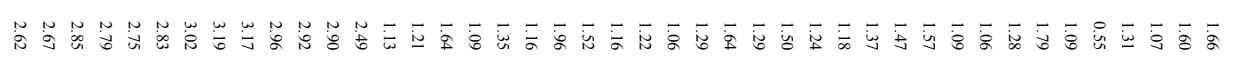

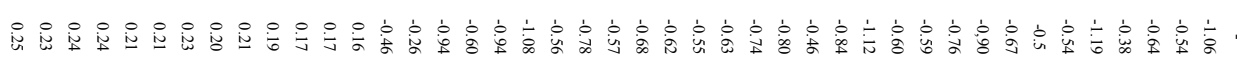

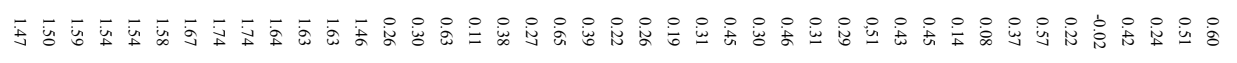

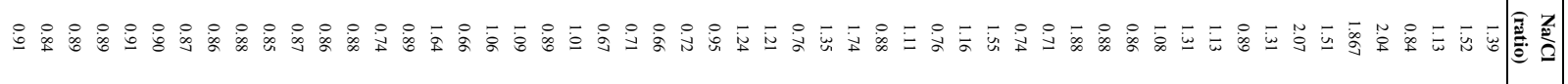

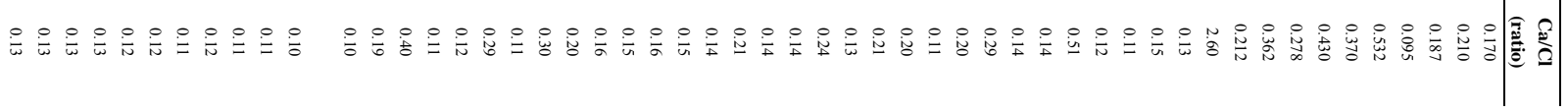




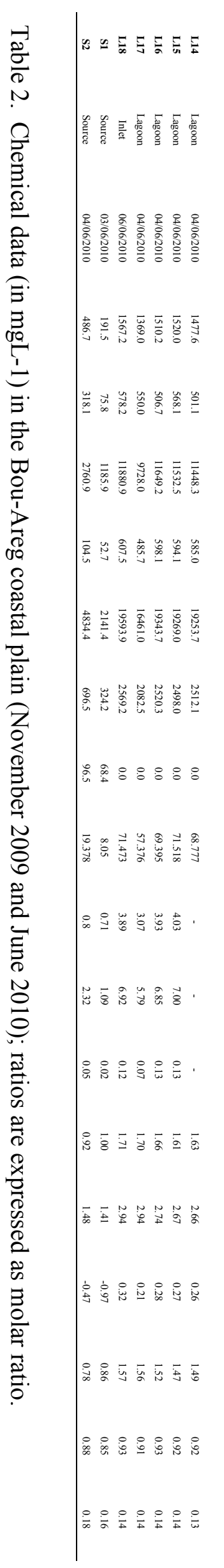




\begin{tabular}{|c|c|c|c|c|c|c|c|}
\hline Code & Nature & Sampling date & $\begin{array}{l}\delta^{18} \mathrm{O} \\
(8 \%) \\
\end{array}$ & $\begin{array}{c}\delta^{2} \mathbf{H} \\
(\delta \%) \\
\end{array}$ & $\begin{array}{l}\delta^{13} \mathrm{C} \\
(8 \%) \\
\end{array}$ & $\begin{array}{c}\delta^{15} \mathrm{~N}_{-\mathrm{N} 03} \\
(\delta \% \%) \\
\end{array}$ & $\begin{array}{c}8^{18} \mathrm{O}_{-\mathrm{No}} \\
(\mathbf{6} \%)\end{array}$ \\
\hline P1 & Well & $26 / 11 / 2009$ & -5.09 & -36.71 & -7.07 & 10.61 & 10.0 \\
\hline P2 & Well & $26 / 11 / 2009$ & -5.34 & -37.82 & -5.86 & - & - \\
\hline P3 & Well & $26 / 11 / 2009$ & -5.34 & -35.23 & -8.34 & 5.44 & 9.5 \\
\hline P4 & Well & $26 / 11 / 2009$ & -5.19 & -35.65 & -7.91 & 6.80 & 7.9 \\
\hline P5 & Well & 26/11/2009 & -5.05 & -35.78 & -7.82 & 4.54 & 11.3 \\
\hline P6 & Well & $26 / 11 / 2009$ & -5.29 & -38.18 & -11.67 & - & - \\
\hline P7 & Well & $26 / 11 / 2009$ & -5.74 & -39.89 & -5.76 & 10.23 & 11.2 \\
\hline P8 & Well & $26 / 11 / 2009$ & -5.22 & -34.33 & -12.87 & 11.70 & 9.0 \\
\hline P9 & Well & 03/12/2009 & -5.12 & -34.05 & -14.29 & 12.56 & 8.6 \\
\hline P10 & Well & $03 / 12 / 2009$ & -5.24 & -35.54 & -9.83 & & \\
\hline P1 & Well & $02 / 06 / 2010$ & -5.02 & -37.54 & -7.71 & 10.72 & 9.7 \\
\hline $\mathbf{P 2}$ & Well & $02 / 06 / 2010$ & -5.32 & -38.23 & -5.91 & 9.41 & 16.2 \\
\hline P3 & Well & $02 / 06 / 2010$ & -5.21 & -36.58 & -9.02 & 5.20 & 12.8 \\
\hline P4 & Well & 02/06/2010 & -5.09 & -37.51 & -7.83 & 6.09 & 14.7 \\
\hline P5 b & Well & 02/06/2010 & -5.49 & -41.46 & -12.56 & 4.77 & 18.2 \\
\hline P6 b & Well & $02 / 06 / 2010$ & -5.10 & -37.64 & -6.36 & 7.61 & 14.6 \\
\hline P7 b & Well & $02 / 06 / 2010$ & -4.90 & -36.80 & -8.00 & 11.31 & 11.1 \\
\hline P8 & Well & $02 / 06 / 2010$ & -4.92 & -36.96 & -14.20 & 12.06 & 9.3 \\
\hline P9 & Well & $31 / 05 / 2010$ & -4.74 & -33.86 & -13.97 & 12.82 & 9.9 \\
\hline P10 & Well & $01 / 06 / 2010$ & -5.08 & -37.20 & -8.78 & 8.27 & 10.9 \\
\hline P11 & Well & $31 / 05 / 2010$ & -5.10 & -38.48 & -8.08 & 9.71 & 10.3 \\
\hline P12 & Well & $31 / 05 / 2010$ & -4.90 & -38.70 & -9.91 & 6.08 & 10.9 \\
\hline P13 & Well & $31 / 05 / 2010$ & -5.30 & -38.77 & -5.79 & 8.51 & 9.4 \\
\hline P14 & Well & $31 / 05 / 2010$ & -5.01 & -35.89 & -10.52 & 8.35 & 9.5 \\
\hline P15 & Well & $31 / 05 / 2010$ & -5.12 & -36.52 & -9.61 & 6.49 & 10.6 \\
\hline P16 & Well & $31 / 05 / 2010$ & -5.25 & -37.50 & -6.49 & 8.37 & 7.6 \\
\hline P17 & Well & $31 / 05 / 2010$ & -5.25 & -37.97 & -6.85 & 6.28 & 12.4 \\
\hline P18 & Well & $01 / 06 / 2010$ & -4.57 & -32.82 & -10.88 & 6.33 & 10.1 \\
\hline P19 & Well & 01/06/2010 & -5.20 & -37.32 & -6.67 & 7.85 & 10.4 \\
\hline P20 & Well & $01 / 06 / 2010$ & -5.19 & -37.39 & -5.46 & 7.99 & 9.7 \\
\hline P21 & Well & $01 / 06 / 2010$ & -5.11 & -35.49 & -5.31 & 6.84 & 10.8 \\
\hline P22 & Well & 01/06/2010 & -5.13 & -36.42 & -6.27 & 5.49 & 10.9 \\
\hline P23 & Well & 01/06/2010 & -5.47 & -39.13 & -8.63 & 7.60 & 12.7 \\
\hline P24 & Well & $01 / 06 / 2010$ & -5.03 & -36.62 & -11.22 & 5.16 & 11.1 \\
\hline P25 & Well & 01/06/2010 & -5.26 & -38.25 & -7.67 & 4.13 & 11.0 \\
\hline P26 & Well & $01 / 06 / 2010$ & -5.11 & -36.52 & -9.24 & 4.39 & 10.3 \\
\hline P27 & Well & $01 / 06 / 2010$ & -5.15 & -33.96 & -5.21 & 8.27 & 12.3 \\
\hline P28 & Well & $02 / 06 / 2010$ & -5.07 & -36.10 & -9.64 & 10.35 & 8.7 \\
\hline P29 & Well & $02 / 06 / 2010$ & -4.77 & -34.01 & -12.38 & 5.83 & 7.9 \\
\hline P30 & Well & 02/06/2010 & -4.98 & -35.48 & -10.74 & 11.81 & 9.7 \\
\hline L1 & Lagoon & 03/06/2010 & 1.14 & 7.58 & -0.88 & - & - \\
\hline L2 & Lagoon & 03/06/2010 & 1.13 & 7.62 & - & - & - \\
\hline L3 & Lagoon & $03 / 06 / 2010$ & 1.18 & 7.93 & - & - & - \\
\hline $\mathrm{L} 4$ & Lagoon & 03/06/2010 & 1.29 & 6.65 & - & - & - \\
\hline L5 & Lagoon & 03/06/2010 & 1.19 & 6.68 & -1.27 & - & - \\
\hline L6 & Lagoon & 03/06/2010 & 1.16 & 6.01 & -1.47 & - & - \\
\hline L7 & Lagoon & $04 / 06 / 2010$ & 1.13 & 6.94 & - & - & - \\
\hline L8 & Lagoon & $04 / 06 / 2010$ & 1.16 & 7.21 & -1.84 & - & - \\
\hline L9 & Lagoon & 04/06/2010 & 1.15 & 6.01 & - & - & - \\
\hline L10 & Lagoon & $04 / 06 / 2010$ & 1.16 & 7.20 & - & - & - \\
\hline L11 & Lagoon & 04/06/2010 & 1.13 & 6.43 & - & - & - \\
\hline L12 & Lagoon & 04/06/2010 & 1.12 & 7.04 & - & - & - \\
\hline L13 & Lagoon & 04/06/2010 & 1.14 & 7.10 & - & - & - \\
\hline L14 & Lagoon & $04 / 06 / 2010$ & 1.12 & 7.27 & - & - & - \\
\hline L15 & Lagoon & 04/06/2010 & 1.20 & 6.55 & -0.48 & - & - \\
\hline L16 & Lagoon & 04/06/2010 & 1.16 & 7.91 & -0.36 & - & - \\
\hline L17 & Lagoon & 04/06/2010 & -0.31 & -3.29 & -6.84 & - & - \\
\hline L18 & Inlet & $06 / 06 / 2010$ & 1.08 & 6.61 & 0.11 & - & - \\
\hline s1 & Source & 03/06/2010 & -4.59 & -27.76 & -13.35 & 11.38 & 12.7 \\
\hline S2 & Source & $04 / 06 / 2010$ & -4.79 & -31.50 & -13.85 & 12.90 & 12.7 \\
\hline
\end{tabular}

Table 3. Isotopic composition $(\delta \%$ ) of groundwater in the Bou-Areg aquifer (November 2009 and June 2010). 
Figure1

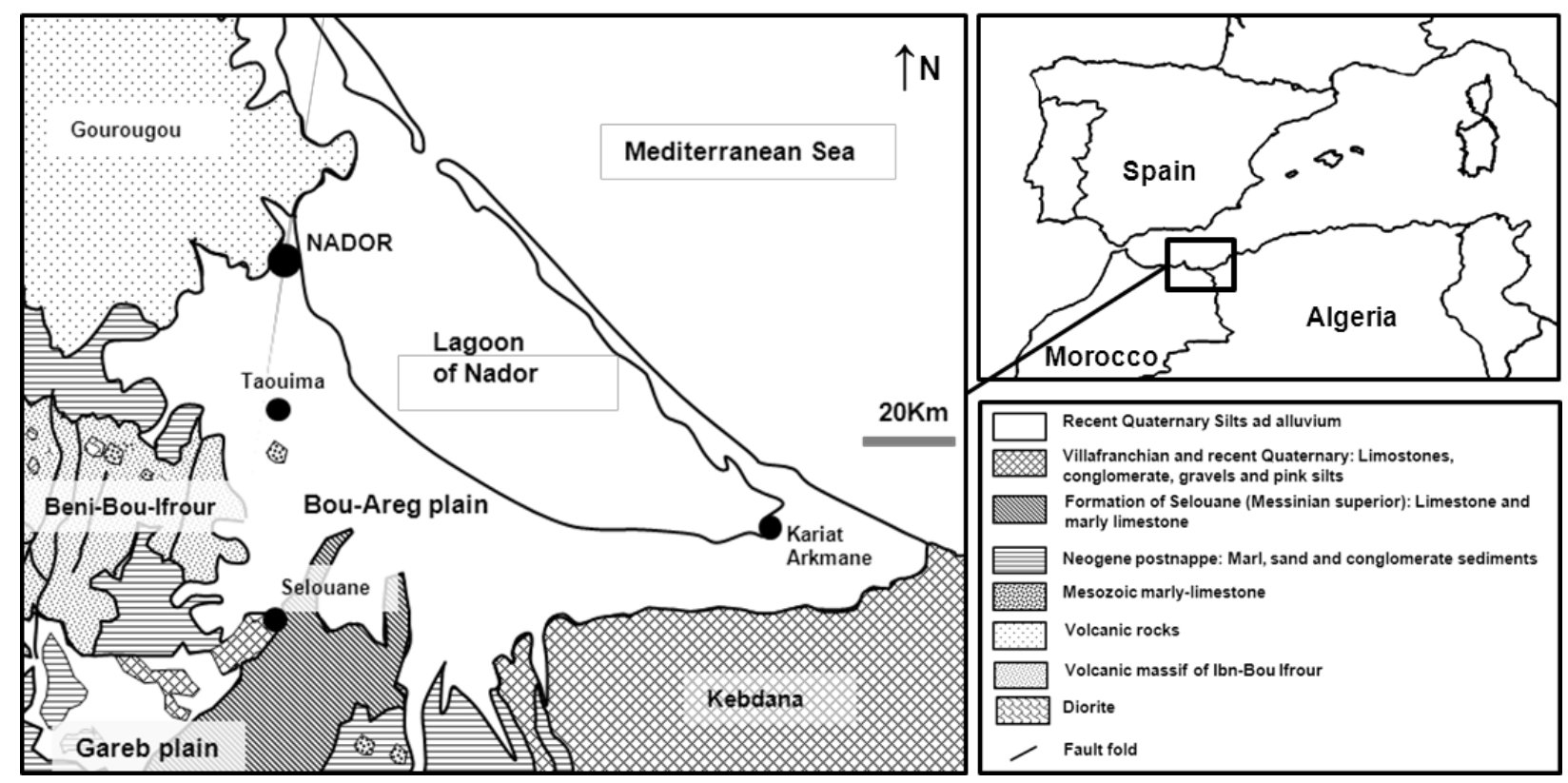

Figure 1 
Figure2
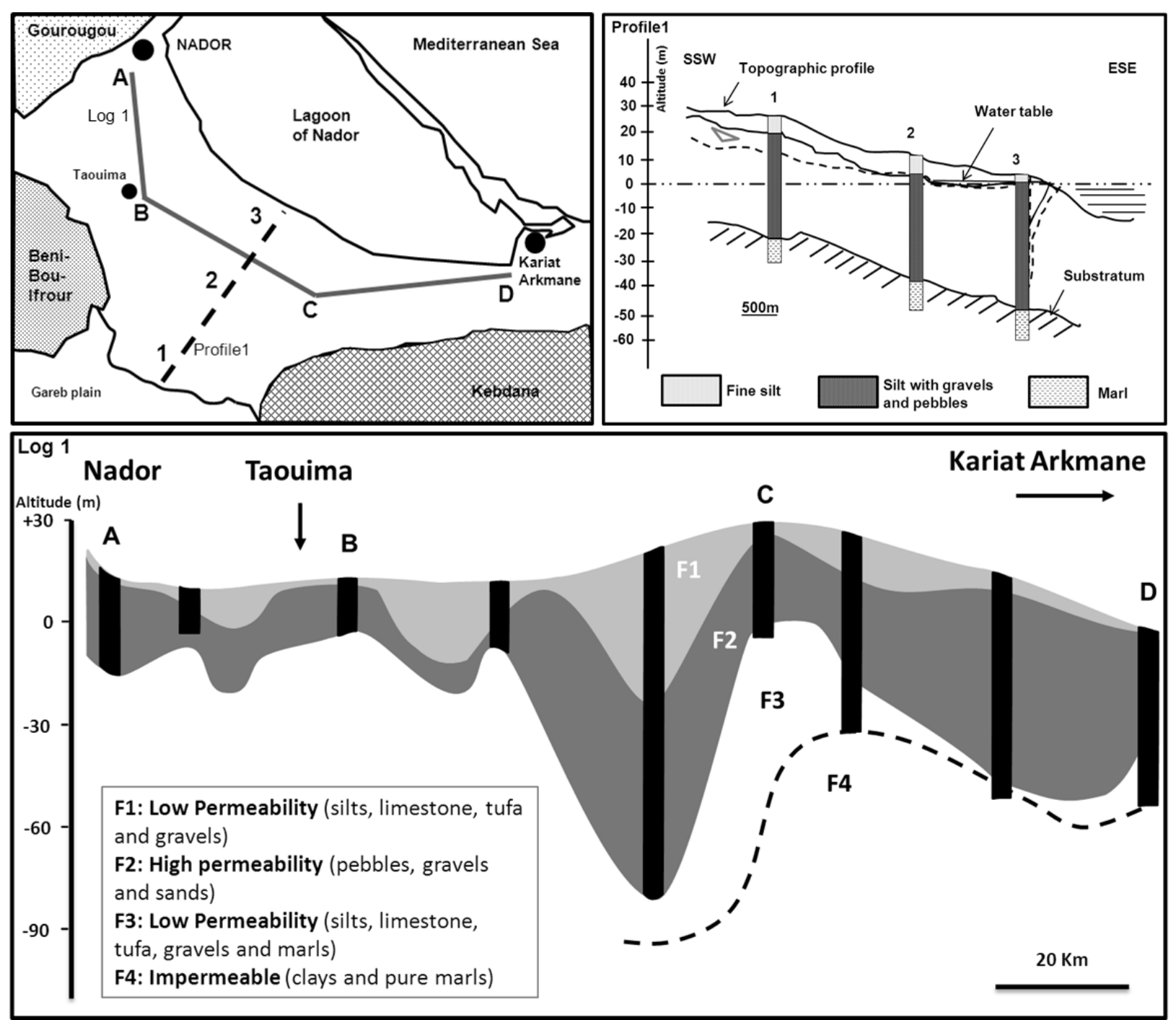

Figure 2. 
Figure3

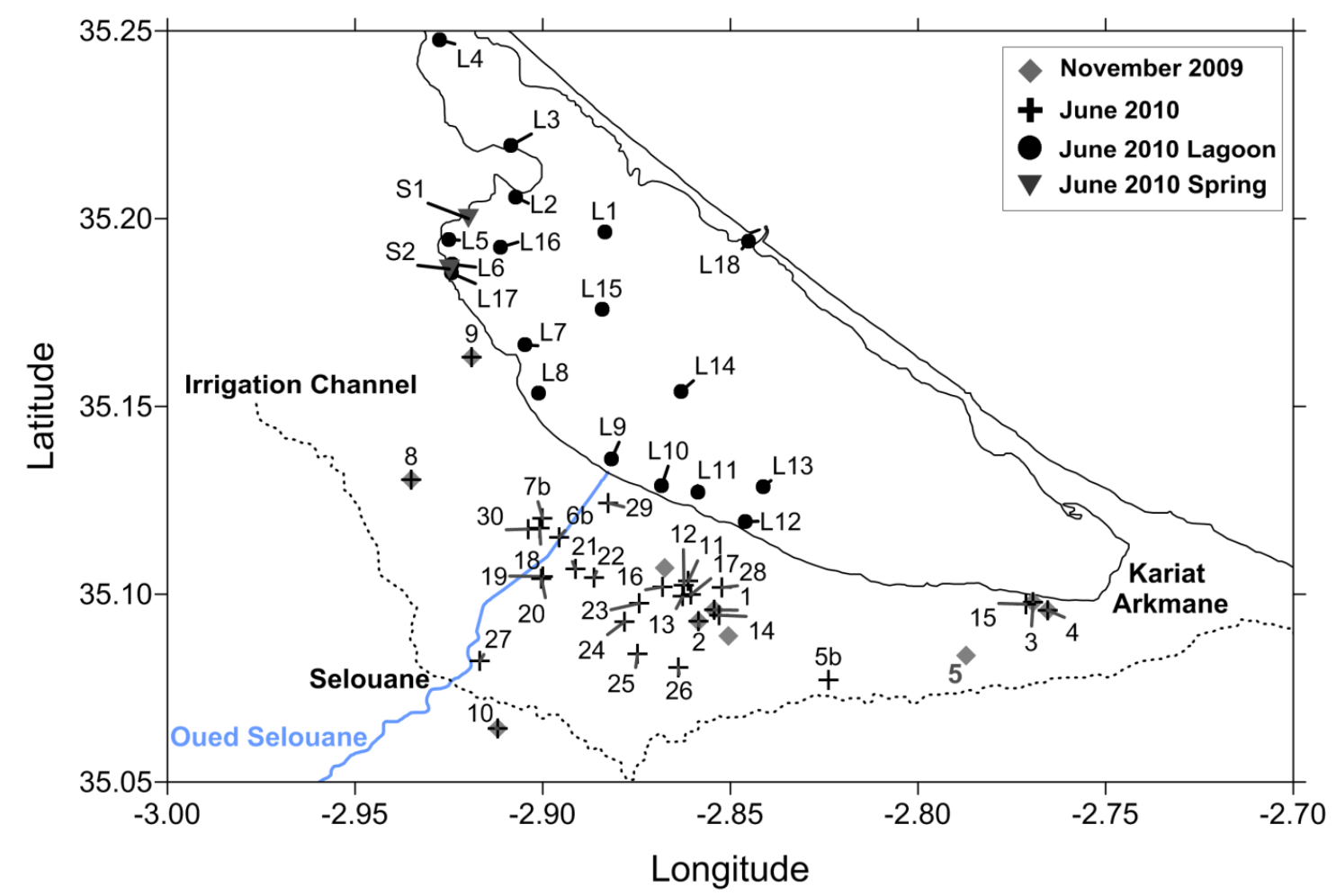

Figure 1. 
Figure4

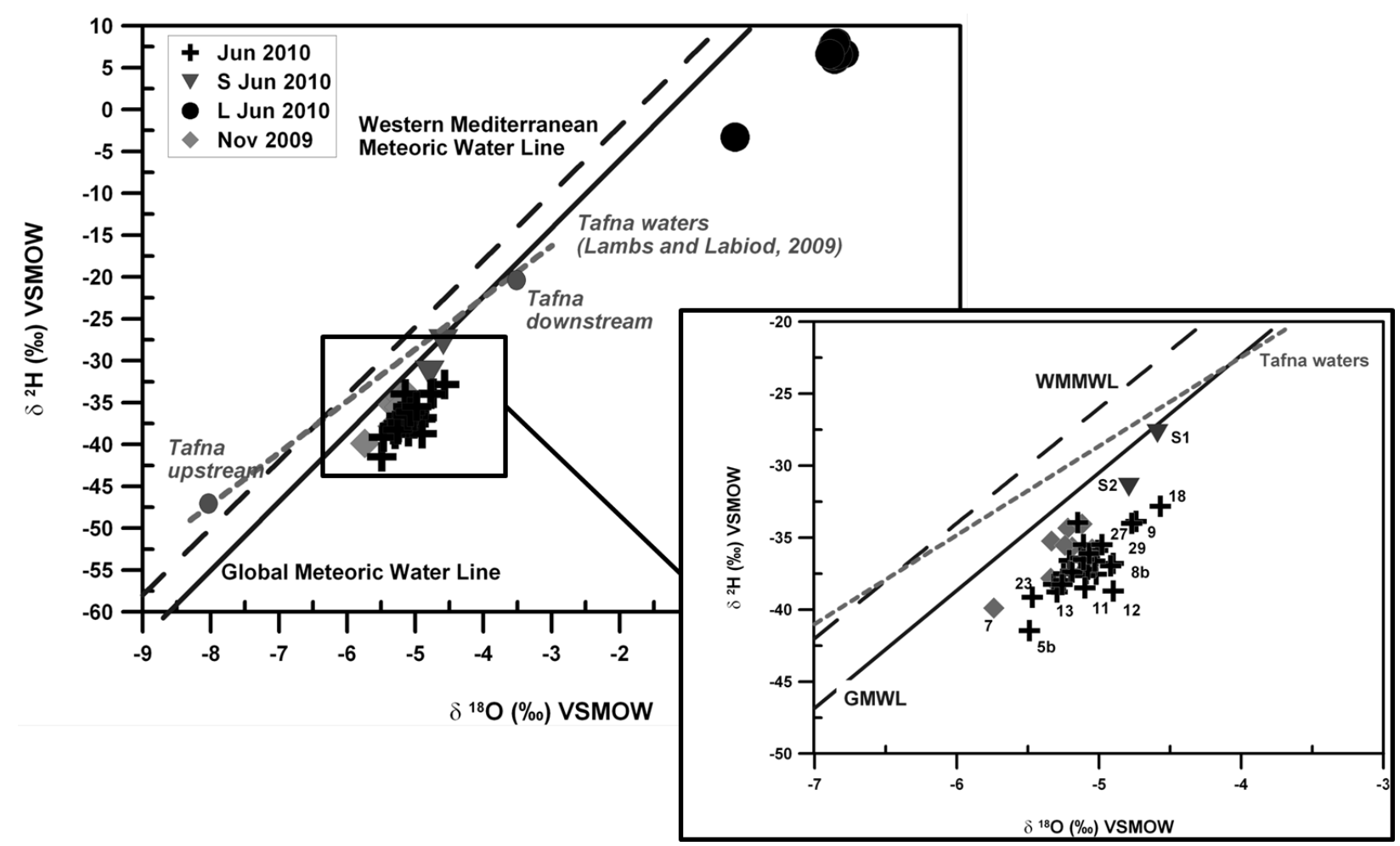

Figure 1. 
Figure5

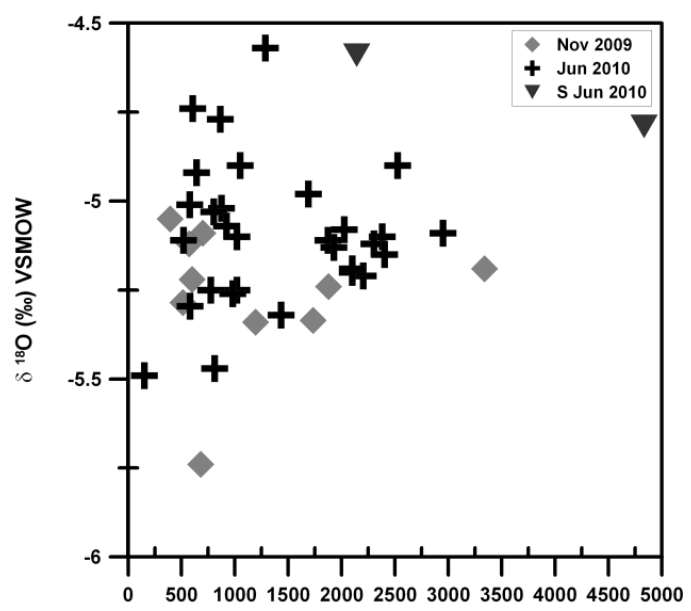

A

Figure 5.

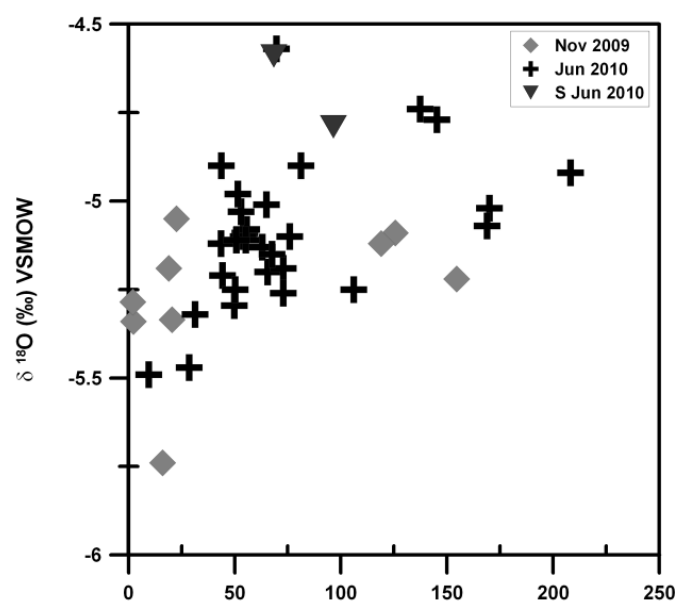

B

$\mathrm{NO}_{3}{ }^{-}\left(\mathrm{mgL}^{-1}\right)$ 
Figure6
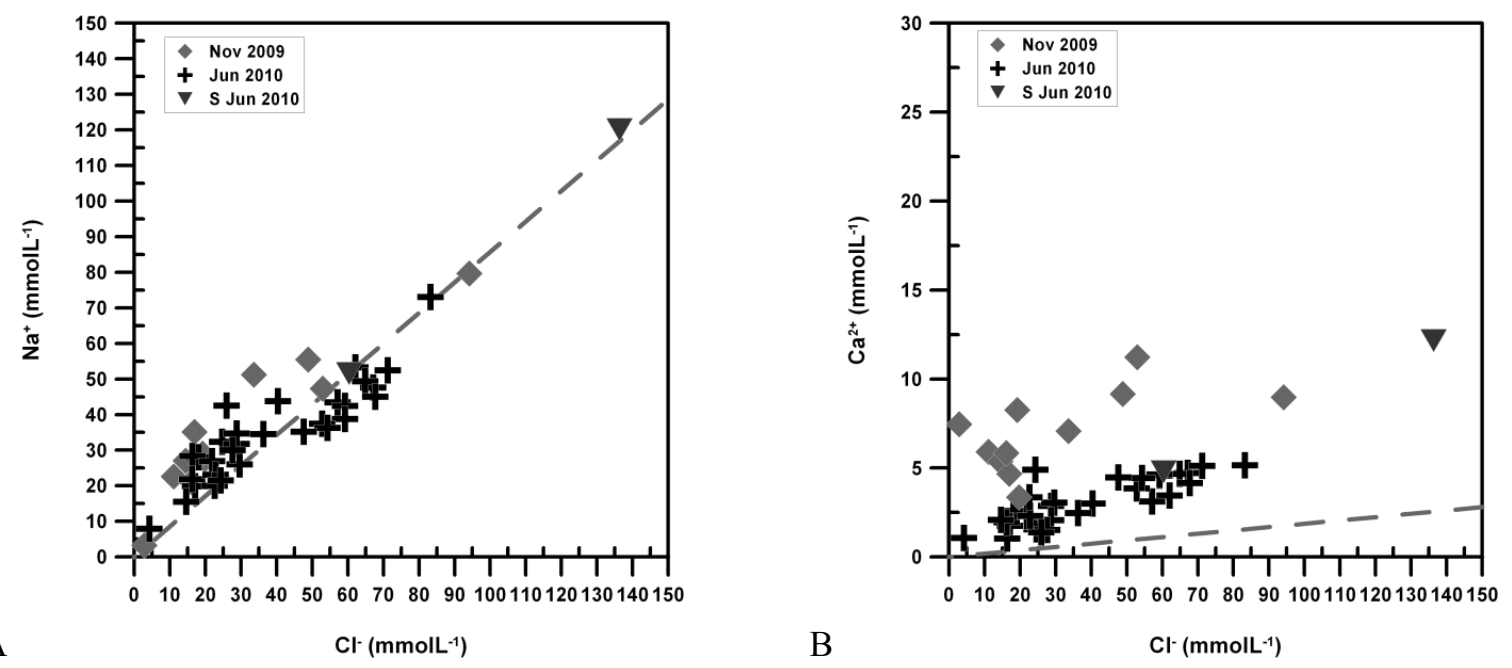

Figure 6. 


\section{Figure7}
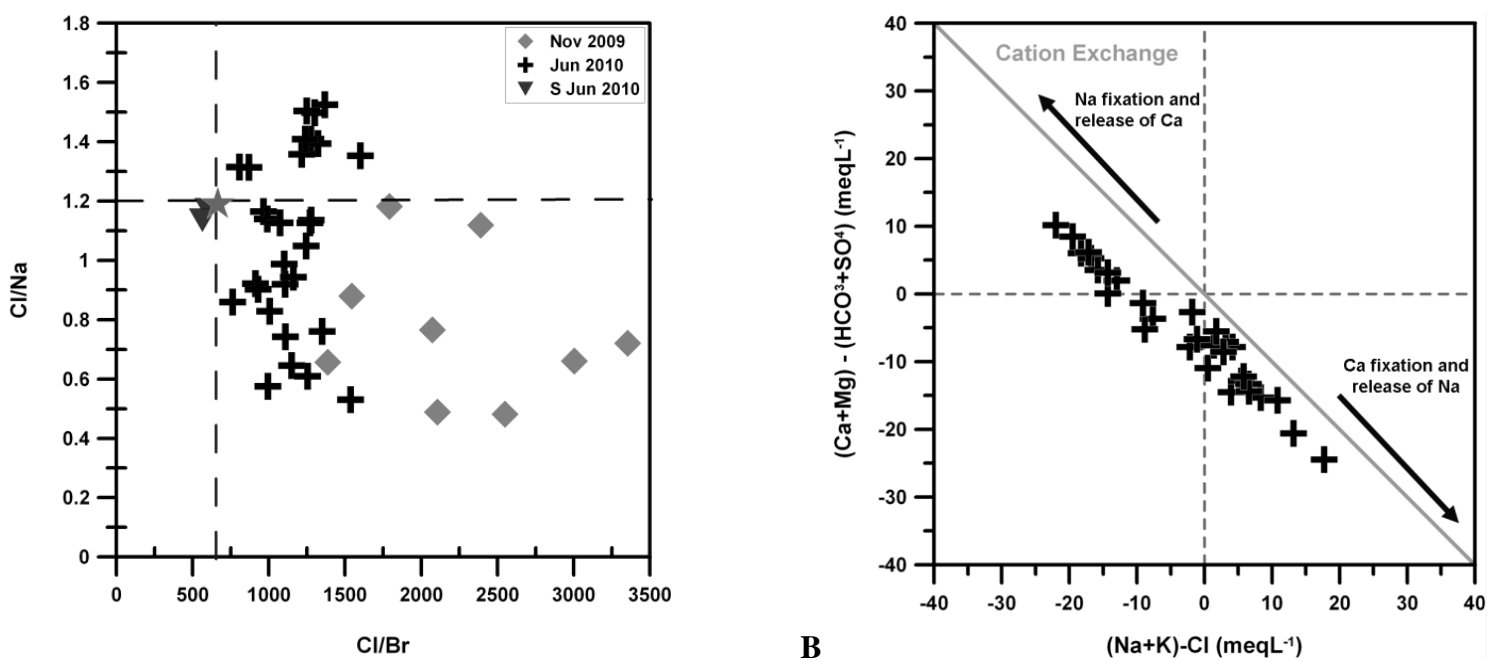

Figure 7. 
Figure8

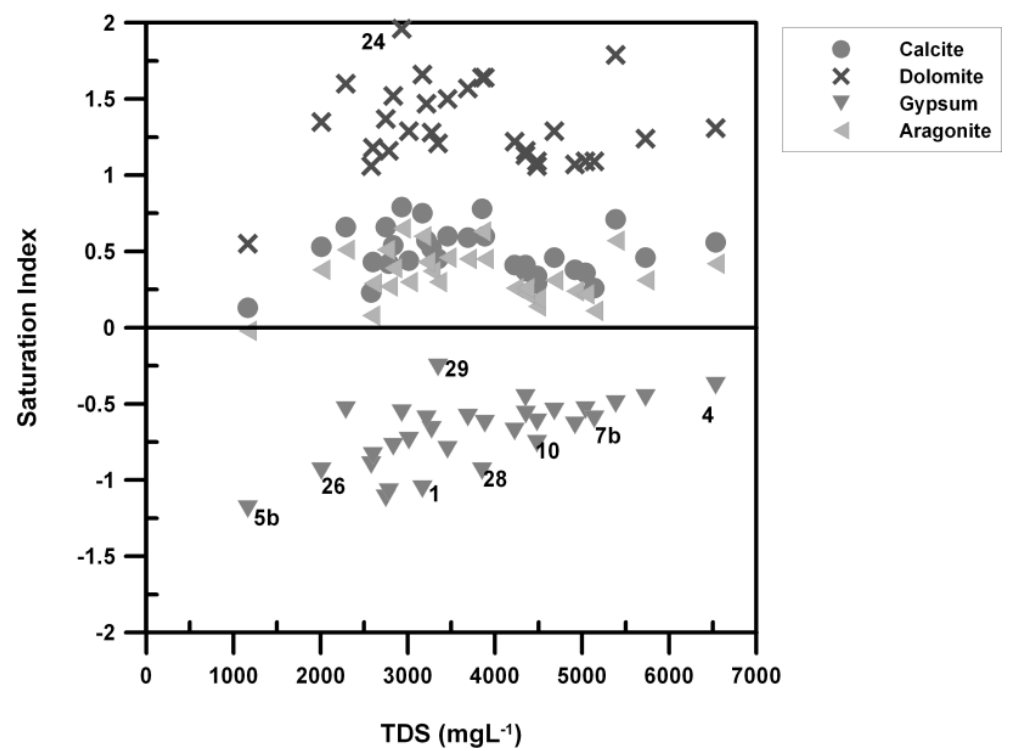

Figure 8. 


\section{Figure9}

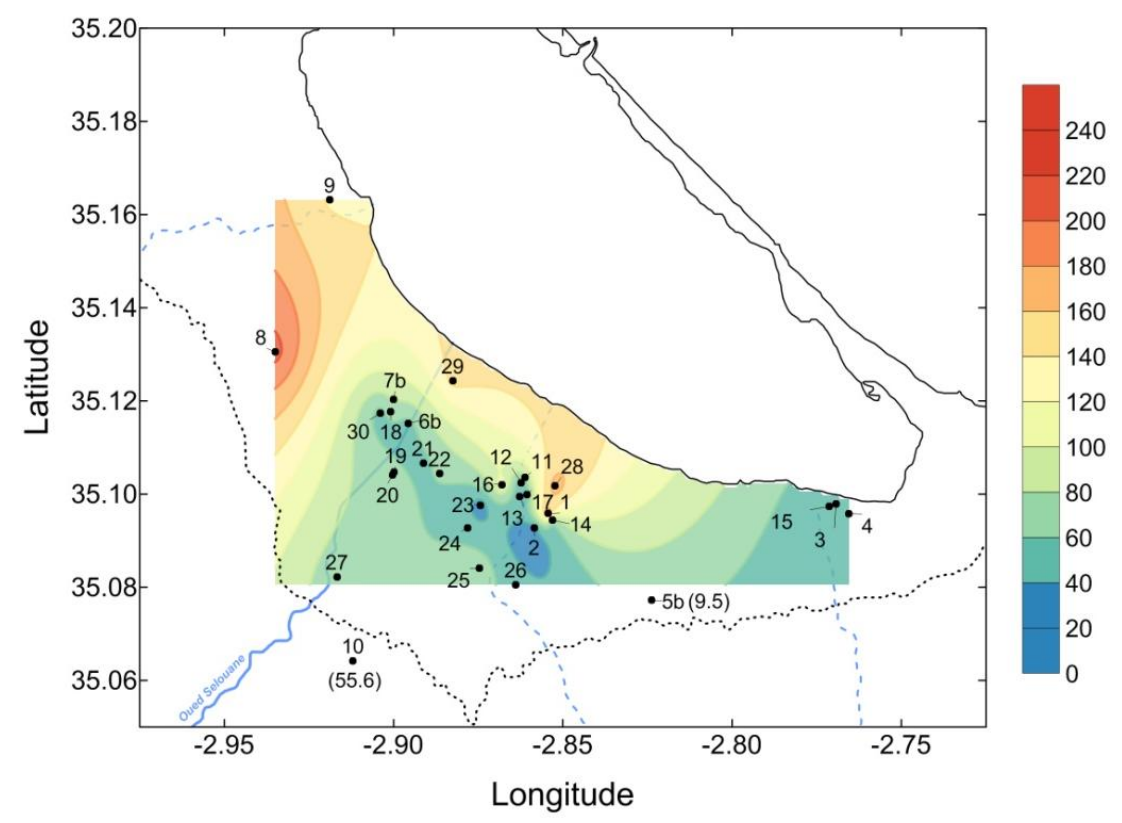

Figure 9. 
Figure10

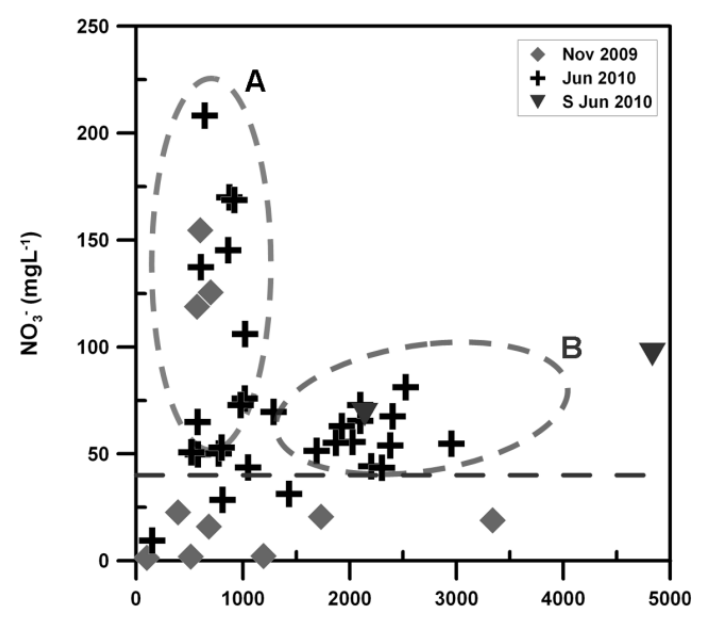

A

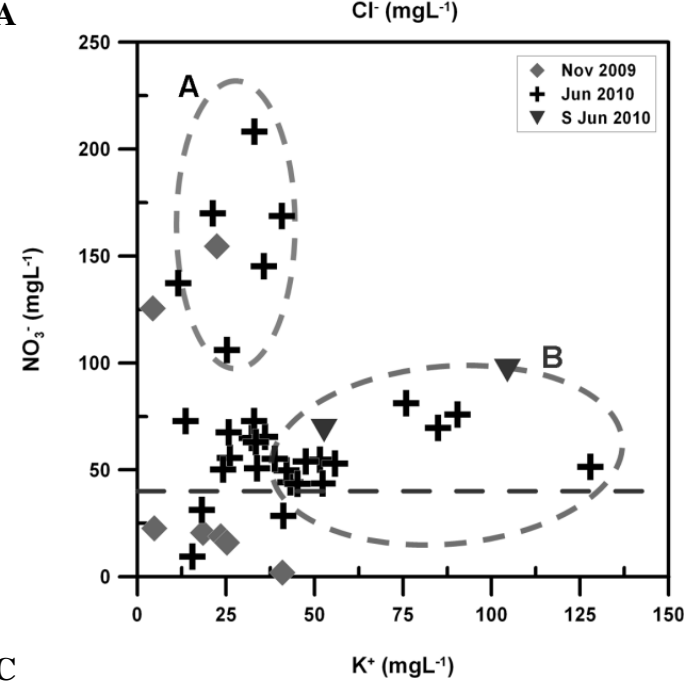

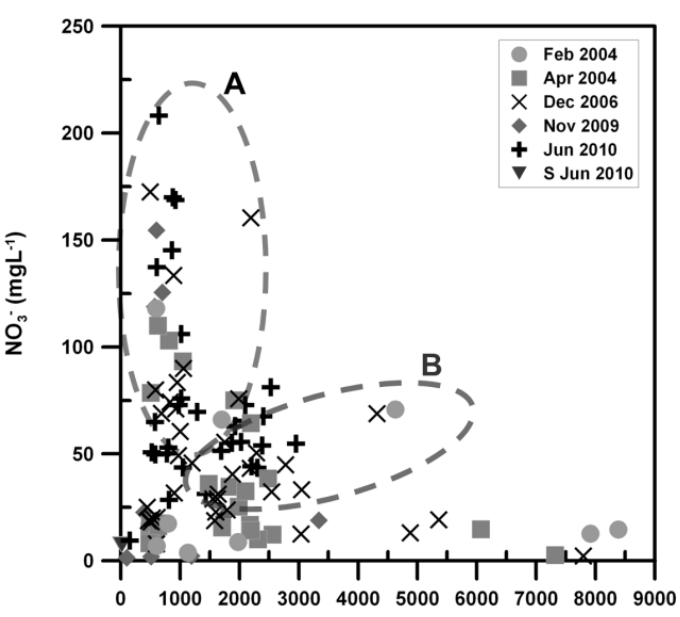

B

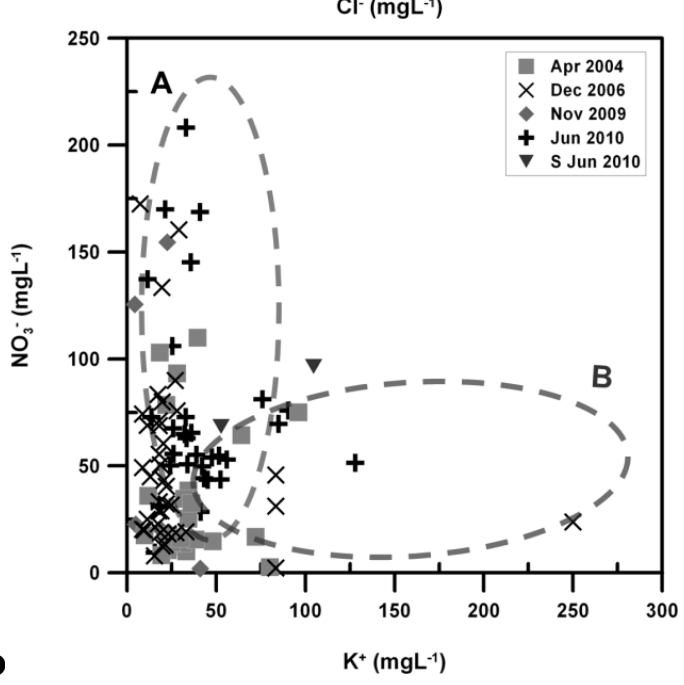

Figure 10. 


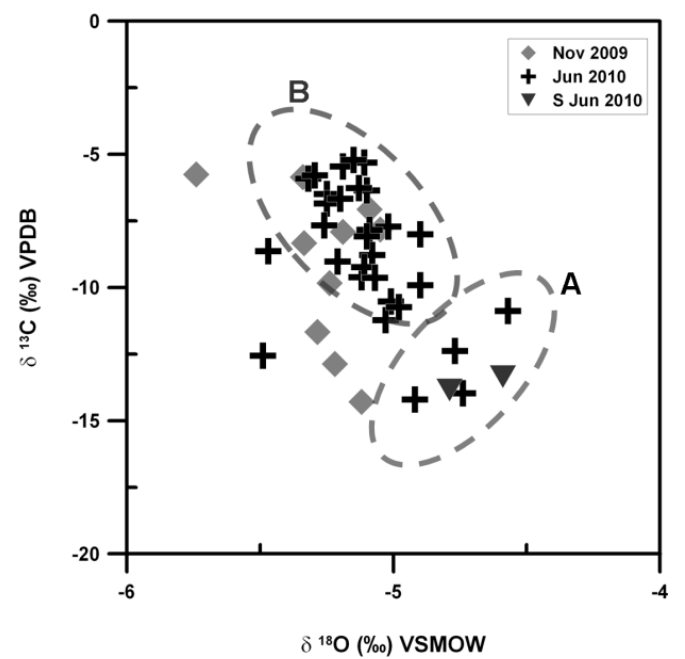

Figure 11. 
Figure12

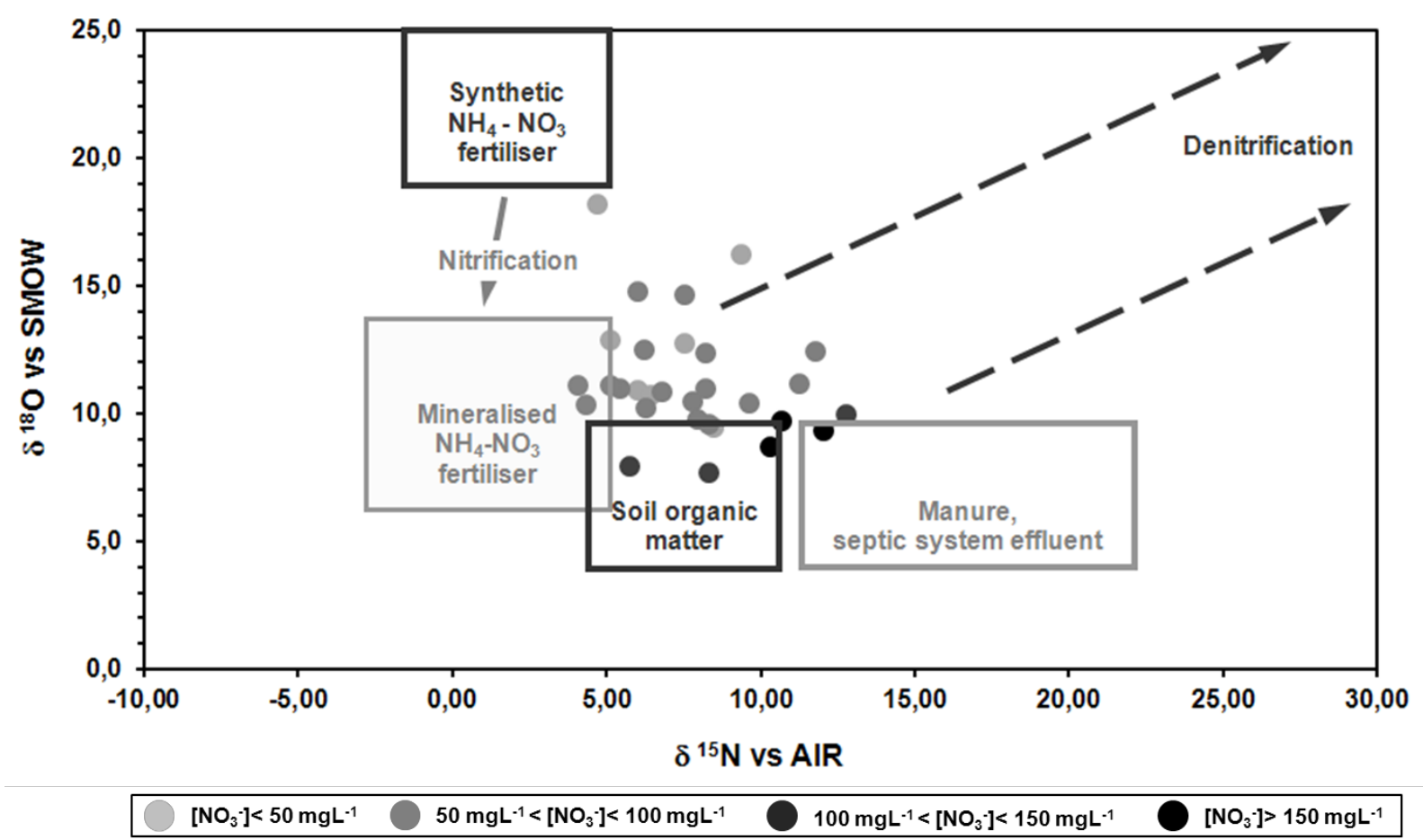

Figure 12. 
Figure13
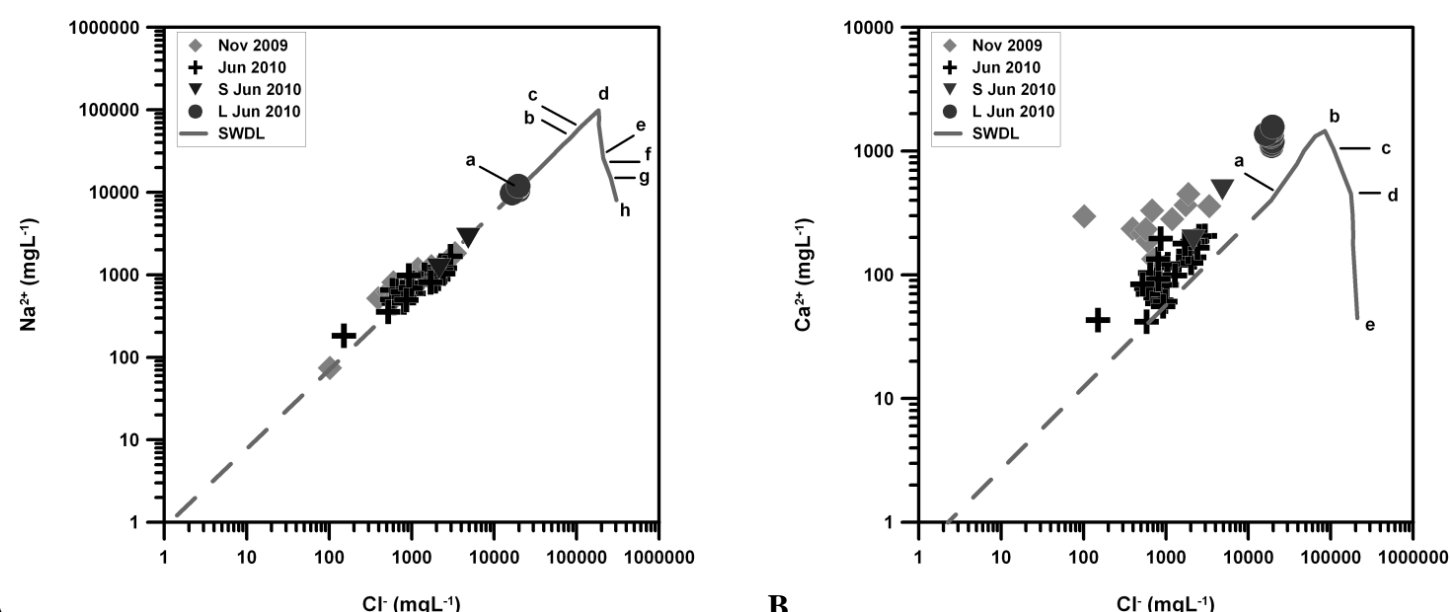

A

$\mathrm{Cl}^{-}\left(\mathrm{mgL}^{-1}\right)$

B

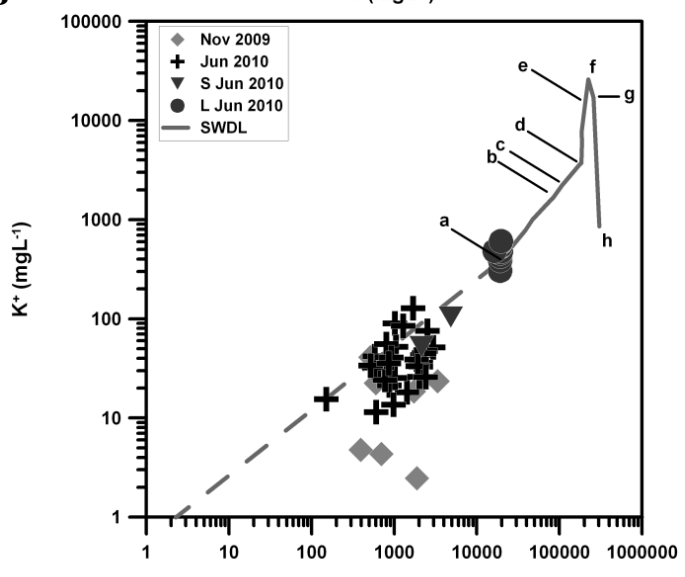

C

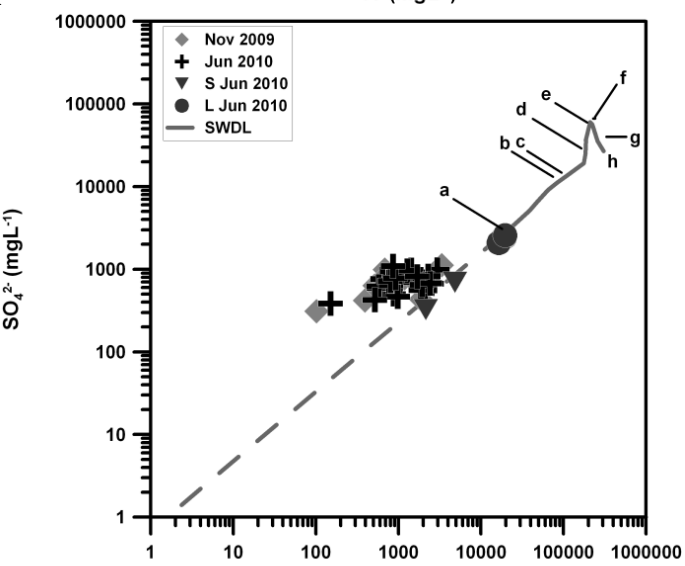

D

$\mathrm{Cl}\left(\mathrm{mgL}^{-1}\right)$

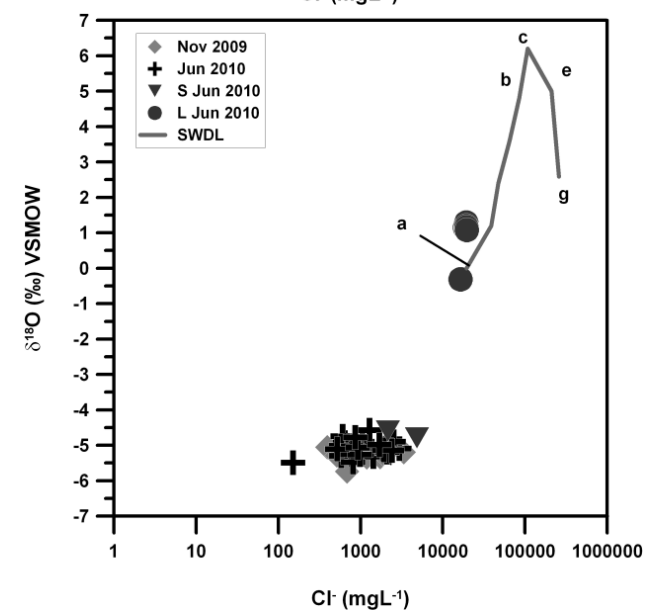

E

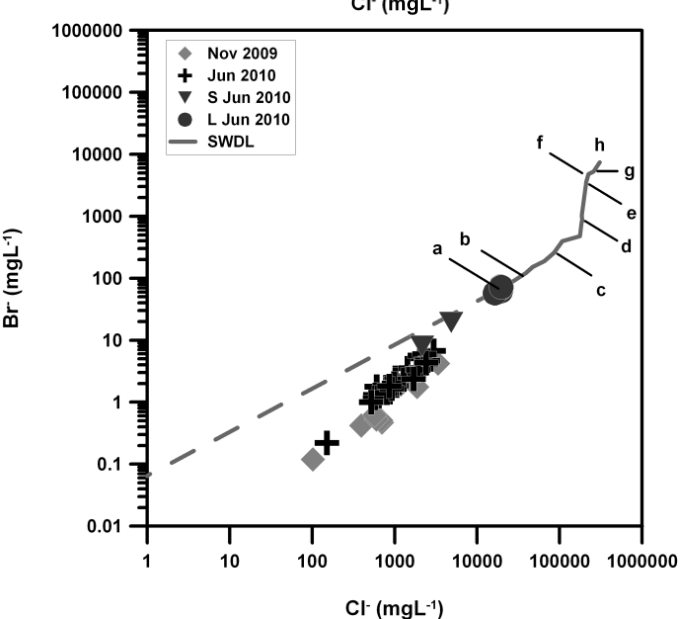

F

$\mathrm{Cl}\left(\mathrm{mgL}^{-1}\right)$

Figure 1. 